\title{
Sivrice-Elazığ Depreminin TUSAGA-Aktif İstasyonlarının Konumlarına Olan Etkisinin Web Tabanlı GPS Yazılımları İle İrdelenmesi
}

\author{
Berkant KONAKOĞLU ${ }^{1 *}$, Alper AKAR ${ }^{2}$ (D) \\ ${ }^{1}$ Amasya Üniversitesi, Teknik Bilimler Meslek Yüksek Okulu, Harita ve Kadastro Programı, Amasya \\ ${ }^{2}$ Erzincan Binali Yıldırım Üniversitesi, Meslek Yüksek Okulu, Harita ve Kadastro Programı, Erzincan
}

Geliş / Received: 27/03/2020, Kabul / Accepted: 30/08/2020

\begin{abstract}
Öz
TUSAGA-Aktif (Türkiye Ulusal Sabit GNSS Ağ1-Aktif) sistemi, Türkiye Cumhuriyeti ve KKTC' ye yerleştirilen 158 adet sabit GNSS (Global Navigation Satellite System) istasyonu ile, ticari ve akademik çalışmalar için kullanıma sunulmuştur. 24 Ocak 2020 tarihinde Doğu Anadolu Fay Zonu (DAFZ) üzerinde Sivrice-Elazığ merkezli saat 20:55' de (lokal zaman) aletsel büyüklüğü $\mathrm{MI}=6.6(\mathrm{Mw}=6.5)$ olan şiddetli bir deprem meydana gelmiştir. Deprem, Doğu Anadolu, Güneydoğu Anadolu, Orta Anadolu ve Karadeniz bölgelerinde hissedilmiştir. Sismik olarak oldukça aktif bir bölgede meydana gelen Sivrice-Elazığ depreminin etki alanındaki 24 saat sürekli hizmet veren TUSAGA-Aktif istasyonlarında herhangi bir hareket olup olmadığının incelenmesi gerekmektedir. Bu kapsamda, ELAZ, ERGN, MALY ve SIV1 TUSAGA-Aktif istasyonlarının hareketlerinin büyüklükleri ve yönleri belirlenmiştir. Deprem tarihinden 7 gün önce ve 7 gün sonraki günlere ait 24 saatlik veriler Online Positioning User Service (OPUS) ve Australian Online GPS Processing Service (AUSPOS) web tabanlı veri işleme servislerinde değerlendirilmiş ve günlük kesin koordinat veri setleri elde edilmiştir. Her iki değerlendirme servisi sonuçları birbirlerine benzer ya da yakın sonuçlar vermiştir. Değerlendirme sonucunda ELAZ, ERGN, MALY ve SIV1 istasyonlarında tespit edilen deformasyonlar anlamlı olarak belirlenmiştir.
\end{abstract}

Keywords: TUSAGA-Aktif, GPS, Doğu Anadolu Fay Zonu, OPUS, AUSPOS

\section{Investigation of the Effect of Elazig-Sivrice Earthquake on the Locations of TUSAGA-Active Stations with Web Based GPS Software}

\begin{abstract}
TNPGN-Active (Turkey National Permanent GNSS Network-Active) system, which placed the Republic of Turkey and KKTC with 158 fixed GNSS (Global Navigation Satellite System) station is available for commercial and academic studies. On January 24, 2020, a severe earthquake with an instrumental magnitude $\mathrm{MI}=6.6(\mathrm{Mw}=6.5)$ occurred on the Eastern Anatolian Fault Zone in Sivrice-Elazı̆g center at 20:55 (local Time). The earthquake was felt in Eastern Anatolia, Southeastern Anatolia, Central Anatolia and Black Sea regions. In the study, it was investigated whether there is any change in the locations of TNPGN-Active stations in the impact area of Sivrice-Elazığ earthquake. In this context, the magnitudes and directions of the movements of ELAZ, ERGN, MALY and SIV1 TNPGN-Active stations were determined. 24-hour data 7 days before and 7 days after the earthquake was evaluated in Online Positioning User Service (OPUS) and Australian Online GPS Processing Service (AUSPOS) web-based data processing services, and daily exact coordinate data sets were obtained. The results of both assessment services gave similar or close results. As a result of the evaluation, the deformations detected at ELAZ, ERGN, MALY and SIV1 TNPGN-Active stations were determined significantly.
\end{abstract}

Anahtar Kelimeler: TNPGN-Active, GPS, East Anatolian Fault Zone, OPUS, AUSPOS 


\section{Giriş}

Türkiye, Dünya’ nın sismik olarak en aktif bölgelerinden birini temsil etmektedir (Khalifa, 2018). Ülkemiz Kuzey Anadolu, Doğu Anadolu ve Batı Anadolu fay zonları üzerinde yer almaktadır. Bunlardan Kuzey Anadolu Fay Zonu (KAFZ) ve Doğu Anadolu Fay Zonu (DAFZ) aktif olup, son yllarda oluşan depremler bu fay zonları üzerindeki yerleşim yerlerinde meydana gelmiştir. $\mathrm{Bu}$ durum da bize nüfusumuzun yarısından fazlasının etkin fay hatları üzerinde bulunan yerleşim alanlarında yaşadığını göstermektedir (Kutlu Ünal, 2019). Bu fay sistemlerinden KAFZ, geçen yüzyılın en büyük deprem kırılmalarını üretmiştir (1939 Erzincan depremi Ms> 7.9, 1999 Kocaeli ve Düzce depremi Ms> 7.8) (Menekşe, 2016).
DAFZ ülkemizin tektoniğini kontrol eden ana unsurlardan birisi olup Kuzeydoğuda Karlıova' dan başlayıp Güneybatıda AnadoluArap-Afrika üçlü ekleminin şekillendiği Kahramanmaraş bölgesinde Ölü Deniz Fayı ile birleşir (Altınoğlu, 2019). DAFZ üzerinde en son 24.01.2020 Elazığ Sivrice depreminin yaşandığı tarihe kadar bu bölgede meydana gelen depremler hakkındaki bilgi Tablo 1' de verilmiştir (BDTIM, 2020).

Oluşan depremlerin can kayıları ile sonuçlanmasının en büyük nedeni mühendislik yapılarında meydana gelen deformasyonlardir. Deformasyon, mühendislik yapılarında ve yer kabuğunda kalıc1/geçici etkilerle oluşan şekil değişikliği olarak adlandırılır.

Tablo 1. DAFZ üzerinde meydana gelen büyük depremler

\begin{tabular}{|c|c|c|c|c|c|c|}
\hline Tarih & Saat & Yer & Şiddet & $\begin{array}{l}\text { Mag } \\
\text { (Ms) }\end{array}$ & $\begin{array}{c}\text { Can } \\
\text { Kaybi }\end{array}$ & $\begin{array}{c}\text { Hasarlı } \\
\text { Bina }\end{array}$ \\
\hline 17.08.1949 & $20: 44$ & Karlıova (BİNGÖL) & IX & 6.7 & 450 & 3500 \\
\hline 14.06.1964 & $15: 15$ & MALATYA & VIII & 6 & 8 & 847 \\
\hline 22.05 .1971 & $18: 43$ & BİNGÖL & VIII & 6.8 & 878 & 9111 \\
\hline 5.05 .1986 & $06: 35$ & Doğanşehir(MALATYA) & VIII & 5.9 & 7 & 824 \\
\hline 6.06 .1986 & $13: 39$ & Doğanşehir(MALATYA) & VIII & 5.6 & 1 & 1174 \\
\hline 13.04.1998 & $18: 14$ & Karlıova (BİNGÖL) & VI & 5 & - & 148 \\
\hline 1.05 .2003 & 03:27 & BİNGÖL & VIII & 6.4 & 176 & 6000 \\
\hline 11.08 .2004 & $18: 48$ & Sivrice (ELAZIĞ) & VII & 5.9 & - & - \\
\hline 12.03 .2005 & 09:36 & Karlıova (BİNGÖL) & VI & 5.7 & - & - \\
\hline 14.03.2005 & 03:55 & Karlıova (BİNGÖL) & VII & 5.9 & - & - \\
\hline 23.03 .2005 & $23: 44$ & Karlıova (BİNGÖL) & VI & 5.7 & - & - \\
\hline 6.06 .2005 & $10: 41$ & Karlıova (BİNGÖL) & VI & 5.7 & - & - \\
\hline 9.02 .2007 & $04: 22$ & Sivrice (ELAZIĞ) & VI & 5.5 & - & - \\
\hline 21.02 .2007 & 13:05 & Sivrice (ELAZIĞ) & VII & 5.9 & 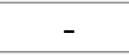 & - \\
\hline 8.03 .2010 & $04: 32$ & Başyurt-Karakoçan & VII & 6.1 & 42 & - \\
\hline 8.03 .2010 & 09:47 & Başyurt-Karakoçan & VI & 5.6 & - & - \\
\hline
\end{tabular}


Mühendislik yapılarında meydana gelen deformasyona depremler, heyelanlar ve plaka hareketleri gibi etkenler neden olur. $\mathrm{Bu}$ yüzden bu hareketlerin belirlenerek gerekli tedbirlerin alınması açısından deformasyon izleme çalışmaları önemli bir yere sahiptir (Gelişkan, 2019). Uzay jeodezisi, derin fayların davranışı hakkında bilgi veren ve deformasyonunun ölçümlerine imkân sağlayan bir yöntemdir. Bu anlamda GNSS günümüzde en çok kullanılan deformasyon belirleme ve izleme tekniğidir.

1980' li y1lların başından beri GNSS tekniği kullanılarak yeryüzünde meydana gelen heyelan, yüzey hareketleri ve deformasyonların tespiti ile alakalı çalışmalar yapılmaktadır (Şanlıŏlu vd., 2019, Hartinger ve Brunner, 2000). Ülkemizde GNSS tekniği kullanılarak yapılan çalışmalarda, genellikle fay hattı çevresinde bölgesel ya da jeodezik GNSS ağı kurularak, bu ağ üzerindeki GNSS noktalarının deformasyonları, hızları ve olası sismik kayma oranları tespit edilmiştir (Aktuğ vd., 2013, Aktuğ vd., 2016).

GNSS tekniği tek boyutlu, iki boyutlu ve üç boyutlu deformasyonların belirlemesinde sıklıkla kullanılmaktadır (Gelişkan, 2019). Artık günümüzde ülke çapında oluşturulmuş 24 saat kesintisiz ölçüm yapan GNSS ağının var olması yapılan çalışmalarda ileriye dönük tahmin yapabilme imkânını da sağlayacaktır.

Günümüzde pek çok ülke sürekli gözlem yapan sabit GNSS ağlarını kullanmaktadır. Ülkemizde de TUSAGA-Aktif sistemi 2009 y1lından beri kullanıcilara hizmet vermektedir. Bu tür ağlar, kampanya türü ölçü yapılan jeodezik ağlara göre, sürekli ölçüm yapması nedeni ile depremler neticesinde oluşan deformasyonları belirlemede daha etkin sonuçlar vermektedir. Sürekli gözlem yapan sabit GNSS istasyonlarından yüksek doğrulukla veri elde edilebilmesi fay hatlarının izlenmesini kolaylaştırmıştır (Yıldırım vd., 2014, Bülbül vd., 2017, Ansari vd., 2017). Yapılan bu çalışmada TUSAGAAktif verileri kullanılarak Elazığ ili Sivrice ilçesinde meydana gelen depremin ELAZ, ERGN, MALY ve SIV1 TUSAGA-Aktif istasyonlarının konumlarına olan etkisi incelenmiştir. 24 Ocak 2020 tarihinde SivriceElazığ merkez üstünde yerel saat ile 20:55' de aletsel büyüklüğü $\mathrm{Ml}=6.6(\mathrm{Mw}=6.5)$, olan çok şiddetli bir deprem meydana gelmiş ve deprem sonrası hazırlanan tahmini şiddet haritası Şekil 1'de verilmiştir (BDTİM, 2020).

Çalışmada, deformasyon araştırması yapılan istasyonlar Sivrice-Elazığ depreminin olduğu bölgenin çevresinde bulunan TUSAGA-Aktif istasyonlarıdır. Araştırmada 7 gün 24 saat sürekli GNSS ölçüsü kaydı yapan bu istasyonların gözlemleri kullanılmıştır. Veriler OPUS ve AUSPOS web tabanlı veri değerlendirme servislerinde değerlendirilmiştir. Seçilen her bir TUSAGAAktif istasyonuna ait koordinatlar dengelenerek kesin koordinatlar elde edilmiştir.

\subsection{Sivrice Deprem Bölgesinin Fay Zonu Yapısı}

24 Ocak 2020 tarihinde Sivrice (Elazı $\breve{g}$ ) merkezli depremin odak derinliği yaklaşık 5 $\mathrm{km}$ civarında olup sı̆̆ odaklı bir depremdir. Depremin hızlı fay düzlemi çözümü doğrultuatımlı fay olup, Doğu Anadolu Fay Zonu içerisinde meydana gelmiş bir depremdir (BDTIMM, 2020).

Şekil 1'de deprem sonrası hazırlanan tahmini şiddet haritası görülürken (BDTİM, 2020), Şekil 2'de 17 Ocak 2020-2 Şubat 2020 tarihleri arasında Sivrice-Elazı ̆ bölgesinde 
meydana gelen büyük deprem ve artçı şok aktivitesi görülmektedir.

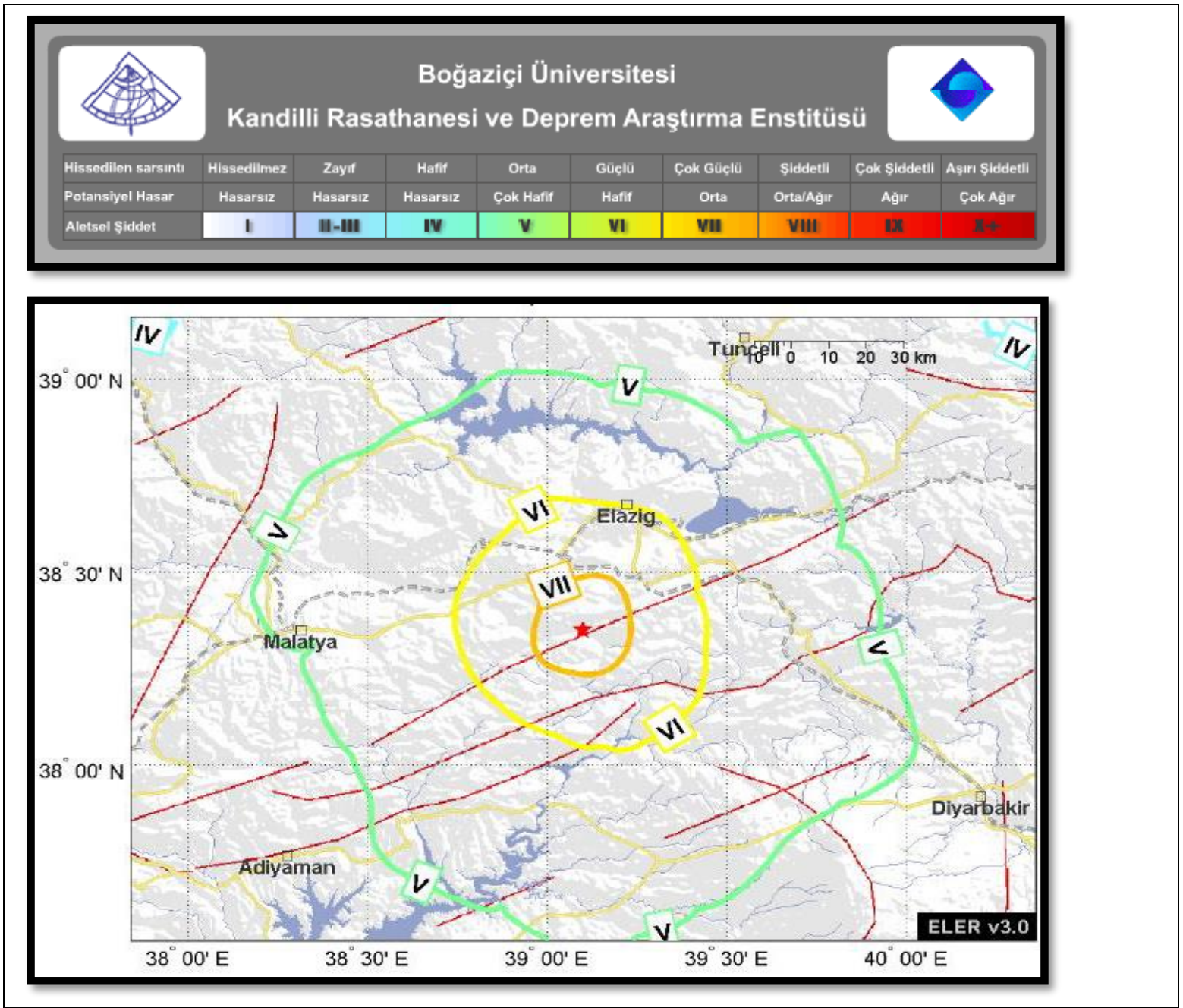

Şekil 1.Deprem sonrası hazırlanan tahmini şiddet haritası

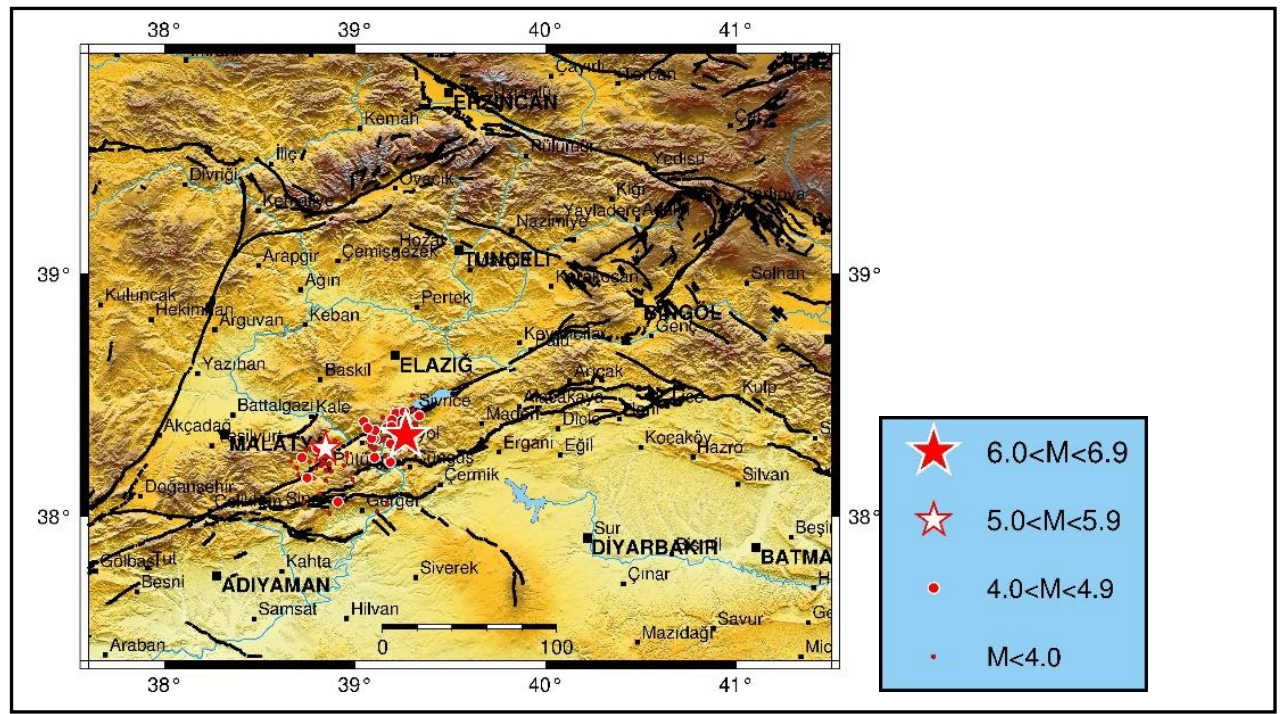

Şekil 2. 17 Ocak 20 Şekil 2. 17 Oc Şekil 2. 17 Ocak 2020-2 Şubat 2020 tarihleri arasında Sivrice-Elazı ̆ depremi ve artçı şok aktivitesi $\mathrm{M}>4$ 
Deprem özellikle dış merkeze yakın UyrukMollaali-Hacılar-Gümüşsu-Günaşl1-AkçaGökçeli-Gözeli-Alıncık-Sivrice' de geleneksel yapı tarzı olan yığma kerpiç-kâgir yapılarda hasar meydana getirmiş olup depremde 41 kişi hayatını kaybetmiştir (BDTİ, 2020).

Türkiye' nin en büyük ikinci fay zonu olan DAFZ, Avrasya ve Arap levhalarının çarpışmalarının sonucu oluşmuştur. DAFZ, Türkiye' nin Güneydoğusundaki Arap / Anadolu levha sınırını oluşturan, morfolojik olarak ayrı ve sismik olarak aktif bir sol yanal doğrultu atımlı faydır. KAFZ ile birlikte, Arap ve Afrika plakaları ile Anadolu Bloğu arasındaki etkileşimi, yanal bir hareketle karşılamaktadır. DAFZ, farklı doğrultu eğim ve hareket bileşenlerine sahip olan farklı fay kollarının oluşturduğu birbirlerinden bağımsız geometrilerde zonal bir yapıdan oluşmaktadır (Tan ve Eyidoğan, 2019; Khalifa, 2018; Khalifa vd., 2018; Köküm, 2019; Yönlü vd., 2017; Kayın, 2019).

DAFZ, Karlıova üçlü eklem noktasından başlar ve Bingöl, Palu, Hazar Gölü, Pötürge, Sincik, Narlı, Türkoğlu yörelerinden geçerek İskenderun Körfezine kadar uzanan geniş bir alanda konumlanır. Kuzeydoğu-Güneybatı doğrultusunda uzanan bu kuşak yaklaşık 700 km uzunluğunda olup, ortalama $30 \mathrm{~km}$ genişliktedir. Bu kuşak içerisinde çok sayıda paralel veya yarı paralel sol yanal atımlı faylar bulunmaktadır. $\mathrm{Bu}$ faylarda sıçrama (stepover), ayrılma, bükülme (bending) ve yön değiştirmelere rastlanmaktadır (Bayramoğlu, 2020).

Kuzey Anadolu Fayı' nın (KAF) Doğu kısmının büyük depremler ürettiği ve 0 ila 15 km derinlikte birleştiği düşünülmektedir. Öte yandan, basit geri kayma modelleri DAFZ' nin zayıf bir şekilde bağlandığını ve sadece üst kabuğun ilk kilometrelerinde, 0 ila $5 \mathrm{~km}$ arasında olduğunu göstermektedir. Bu gözlem yirminci yüzyılda kaydedilen düşük sismisite oranına uygundur (Menekşe, 2016).

Çalışma alanının bulunduğu Elazı̆̆ ili ve çevresi birbirinden farklı iki ayrı deprem bölgesinden oluşmaktadır. Türkiye Deprem Bölgeleri Haritasına göre Elazığ kent merkezinin bulunduğu alan ile Kuzey bölümü tümüyle 2. derece deprem bölgesi içinde yer alırken, Palu İlçesinin de üzerinde yer aldığ Doğu Anadolu Fay Zonu üzerinde kalan, Elazı̆̆ güneyindeki bölge ise 1. Derece deprem bölgesi içindedir (Bayramoğlu, 2020).

Şekil 3'de depremin yaşandığı bölgenin Türkiye deprem tehlike haritasındaki durumu gösterilmiştir (AFAD, 2020).

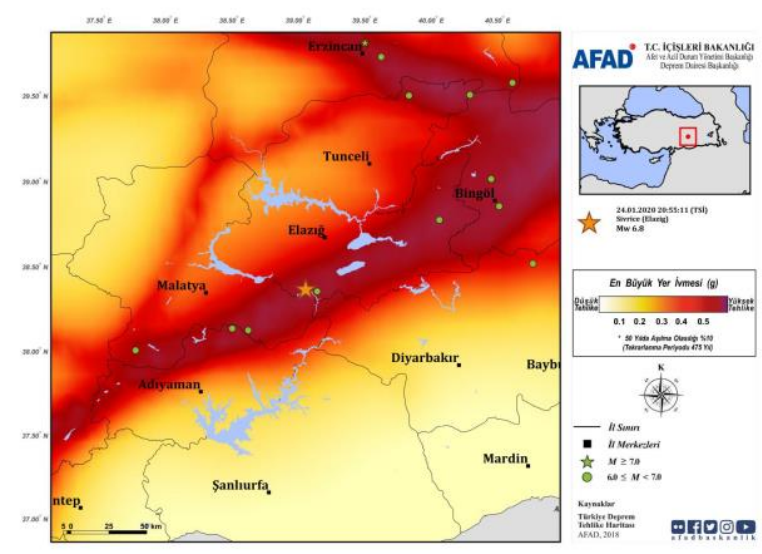

Şekil 3.Türkiye Deprem Tehlike Haritasına göre bölgenin deprem tehlikesi

\section{Materyal ve Metot}

\subsection{Online Positioning User Service (OPUS)}

OPUS, Amerikan Ulusal Okyanus ve Atmosfer İdaresinin kurmuş olduğu bir değerlendirme servisidir. Kullanımı oldukça kolay olan bu değerlendirme sisteminde, kullanıcı gözlem dosyasını sisteme yükleyip, anten tipini, yükseklik bilgisini ve sonuçların 
gönderileceği e-mail adresini sisteme tanımlar. Son aşama olarak ölçülerin hızl1statik (15 dakika ile 2 saat arası) veya statik (2 saat ile 48 saat arası) ölçü yöntemlerinden birini seçerek değerlendirme işlemine başlamış olur. Değerlendirme aşamasında referans olarak çalışma bölgesine en yakın 3 CORS (Continuously Operating Reference Station) veya IGS (International GNSS Service) istasyonu seçilir. $\mathrm{Bu}$ istasyonlar kullanıcı tarafindan değiştirilebilmektedir. Servis statik değerlendirmede PAGES yazılımını kullanmaktadır. Desteklediği uydu sistemi sadece GPS (Global Positioning System)' dir. Sonuçları ITRF2014 (International Terrestrial Reference Frame 2014) ölçü epoğunda verirken, kartezyen koordinat sisteminin yanında UTM (Universal Transverse Mercator) koordinat değerlerini de vermektedir. Değerlendirme servisinin ara yüzüne https://www.ngs.noaa.gov/OPUS/ adresinden ulaşılabilmektedir.

\subsection{Australian Online GPS Processing Service (AUSPOS)}

GeoScience Australia tarafından işletilen bir değerlendirme servisidir. $\mathrm{Bu}$ değerlendirme sisteminde, OPUS servisinde olduğu gibi kullanıcı gözlem dosyasını sistem üzerinden yüklemektedir. Ayrıca ftp üzerinden de veri yüklenebilmektedir. Sistem üzerine kullanıcı tarafindan anten tipi, yükseklik bilgisi ve sonuçların gönderileceği e-mail adresi tanımlanır. OPUS değerlendirme servisinde olduğu gibi bu serviste de yalnızca GPS verileri değerlendirilmektedir. Sistemin veriyi değerlendirmesi için en az 1 saatlik gözlem toplanmış olmalıdır. Değerlendirme, çalışma bölgesine yakın 12-15 IGS istasyonu referans seçilerek yapılır. Statik değerlendirmede Bernese akademik yazılımını kullanmaktadır. Sonuçlar ITRF2014 sisteminde verilirken, kartezyen koordinat sisteminin yanında coğrafi koordinatlar ve UTM koordinat değerleri de verilmektedir. Değerlendirme servisinin ara yüzüne http://www.ga.gov.au/cgi-perl/auspos/gps.pl adresinden ulaşılabilmektedir.

\subsection{Uygulama}

Çalışmanın bu kısmında, 24 Ocak 2020 tarihinde meydana gelen Sivrice-Elazı ğ $(\mathrm{Ml}=6.6)$ depremi tahmini şiddet haritası sınırları içerisinde kalan ELAZ (Elazığ), ERGN (Ergani), MALY (Malatya) ve SIV1 (Siverek) TUSAGA-Aktif istasyonlarının verileri kullanılmış ve istasyonların dağılımı şekil 4'te gösterilmiştir. Deprem merkezinin TUSAGA-Aktif istasyonlarından ELAZ istasyonuna uzaklığı yaklaşı $32 \mathrm{~km}$, ERGN istasyonuna uzaklığ yaklaşık $58 \mathrm{~km}$, MALY yaklaşık $77 \mathrm{~km}$ ve SIV1 istasyonuna uzaklığ1 yaklaşık 72 km'dir.

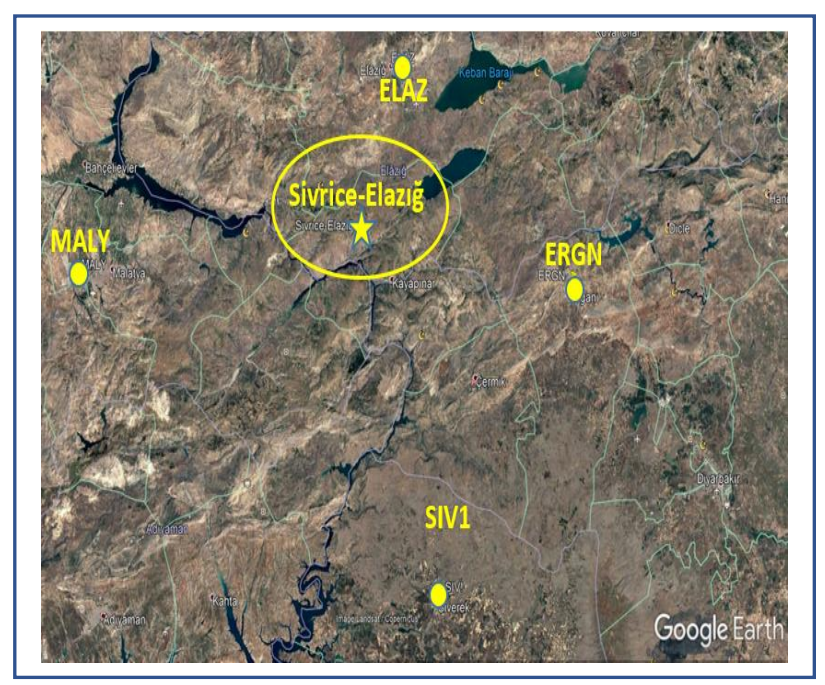

Şekil 4. Çalışmada kullanılan TUSAGAAktif İstasyonları

24 Ocak 2020 tarihinde meydana gelen $\mathrm{Ml}=6.6 \quad$ şiddetindeki Sivrice-Elazı depreminden bir sonraki haftaya kadar meydana gelen deprem sayısında azalma olduğu görülmüştür. Yapılan bu tespite göre deprem yoğunluğu ilk yedi gün içerisinde olduğu için 24 Ocak 2020 tarihli Sivrice- 
Elazığ depremi için 17 Ocak 2020-2 Şubat 2020 tarihleri arasındaki veriler değerlendirilmiştir. Çalışmada kullanılan bu veri setleri Tapu ve Kadastro Genel Müdürlüğ̈̈ tarafından yayınlanan https://www.tusagaaktif.gov.tr/Sayfalar/Rinex/30snRinex.aspx adresinden sağlanmıştır. Yukarıda verilen tarihler arasında 24 saat süreli ve 30 saniye periyotlu verilerin her biri OPUS ve AUSPOS rölatif değerlendirme servislerine gönderilmiştir. Kayıt aralığı 1 saniyelik veri yerine 30 saniyelik verilerin kullanılmasının nedeni AUSPOS değerlendirme sisteminin 30 saniyelik verileri kullanmasıdır. 30 saniyelik verilerin kullanılması ile iki farklı web tabanlı değerlendirme servisinin karşılaştırmasının aynı koşullara göre yapılması amaçlanmıştır. Statik olarak değerlendirilen verilerde GPS uydularına ait tüm veriler kullanılmıştır. Değerlendirme işlemi tamamlandıktan sonra değerlendirme raporları önceden sisteme tanımlanan adrese servis tarafindan mail olarak gönderilmiştir. Statik verilerin değerlendirme aşamasında OPUS ve AUSPOS servislerinde "IGS Final" hassas efemeris dosyası kullanılmıştır. 17-23 Ocak 2020 tarihleri arası ölçü epoğundaki ITRF14 sistemindeki kartezyen koordinatların aritmetik ortalama değerleri TUSAGA- Aktif istasyonunun sabit koordinatı olarak alınmış ve deformasyon belirleme aşamasında referans olarak kullanılmıştır. Çalışma kapsamında, TUSAGA-Aktif istasyonlarında oluşan yer değişimlerini yorumlamak için, web servisleri ile hesaplanan kesin kartezyen koordinatlar $(X, Y, Z), \quad$ lokal toposentrik kartezyen koordinatlara $(n, e, u)$ aşağıdaki bağıntılar kullanılarak dönüştürülmüştür.

Burada $X_{0}, Y_{0}, Z_{0}$ referans noktasinın yer merkezli kartezyen koordinatlarını; $\Phi_{0}, \lambda_{0}$ referans noktasının $X_{0}, Y_{0}, Z_{0}$ yer merkezli kartezyen koodinatları ile hesaplanan coğrafi koordinatlarını; $X_{i}, Y_{i}, Z_{i}, \quad i$. noktanın yer merkezli kartezyen koordinatların; $n_{i}, e_{i}, u_{i}$ ise $i$. noktanın lokal toposentrik kartezyen koordinatlarını göstermektedir.

$$
R\left(\varphi_{0}, \lambda_{0}\right)=\left[\begin{array}{ccc}
-\sin \lambda_{0} & \cos \lambda_{0} & 0 \\
-\sin \varphi_{0} \cos \lambda_{0} & -\sin \varphi_{0} \sin \lambda_{0} & \cos \varphi_{0} \\
\cos \varphi_{0} \cos \lambda_{0} & \cos \varphi_{0} \sin \lambda_{0} & \sin \varphi_{0}
\end{array}\right]
$$

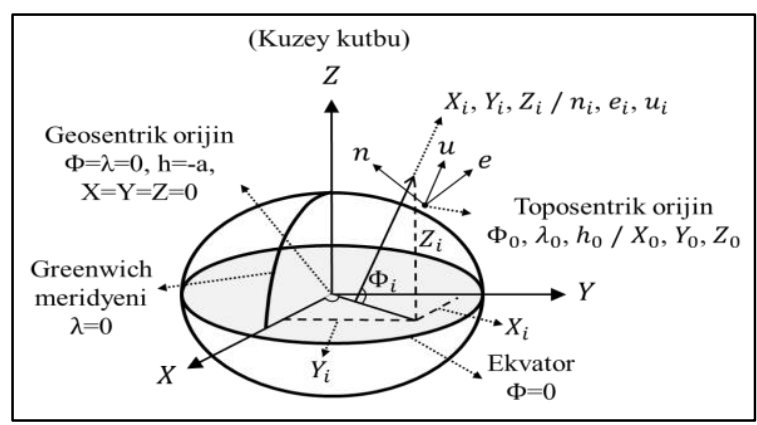

Şekil 5. Jeosentrik ve toposentrik koordinat sistemleri (Yiğit, 2016).

Sivrice-Elazığ depreminden önceki ilk 7 güne ait toposentrik koordinatların standart sapma $(\sigma)$ değerleri, aşağıdaki eşitlikten hesaplanmıştır.

$\sigma= \pm \sqrt{\frac{V V}{n}}$

Eşitlikte $\mathrm{n}$ değeri gün sayısını göstermekte olup bu çalışmada duruma göre 2 ve 7 alınmıştır.

$\mu$ değeri, TUSAGA-Aktif istasyonlarının her gün için hesaplanan toposentrik koordinatların tüm yönlerinde beklenen değer olmak üzere,

$P(\mu-3 \sigma<X<\mu+3 \sigma)=\% 99$

eşitliği kabul edilebilir en büyük hata değerini ifade eder. Bulunan kesin değerlerin güven aralığının dişına çıkması durumunda TUSAGA-Aktif istasyonunun deformasyona uğradığı söylenebilir. 
3. Bulgular ve Tartışma

3.1. OPUS ile yapılan değerlendirme sonuçları

OPUS değerlendirme servisi ile ilk yedi güne ait elde edilen kartezyen koordinatların aritmetik ortalama koordinat değerleri Tablo 2' de verilmektedir. ERGN istasyonunda, referans olarak kullanılacak ilk 7 gün içerisinden yalnızca 18 Ocak ve 19 Ocak 2020 tarihleri için bu değerlendirme servisi ile değerlendirme sonuçları elde edilebilmiştir. Diğer günler referans koordinat hesabına dâhil edilmemiştir. OPUS değerlendirme servisinde kullanılan 3 adet sabit IGS noktasina ait detaylar Tablo 3' de verilmektedir.
OPUS değerlendirme servisi ile elde edilen ELAZ, ERGN, MALY ve SIV1 kodlu TUSAGA-Aktif istasyonlarının günlük toposentrik koordinatlarının referans olarak alınan koordinat ile arasındaki farklar sırasiyla Tablo 5, 6, 7 ve 8' de, yer değişim grafikleri de şekil 5, 6, 7 ve 8' de ayrı ayrı verilmiştir.

Sivrice-Elazı̆̆ depreminden kaynaklanan deformasyonları belirlemek için deprem tarihinden sonraki 7 gün için, OPUS servisi ile değerlendirilmiş tüm yönlere ait standart sapma değerlerinin 3 katını geçen deformasyon miktarları Tablo 4' de verilmiştir.

Tablo 2. Çalışma kapsamında deformasyon araştırması için kullanılan TUSAGA-Aktif istasyonlarının OPUS değerlendirme servisi ile elde edilen koordinatlarının aritmetik ortalama değerleri

\begin{tabular}{cccc}
\hline $\begin{array}{c}\text { TUSAGA-Aktif } \\
\text { İstasyon Kodu }\end{array}$ & $\mathbf{X ~ ( m )}$ & $\mathbf{Y ~ ( m )}$ & $\mathbf{Z}(\mathbf{m})$ \\
\hline ELAZ & 3862978.8287 & 3156913.2586 & 3962227.0911 \\
\hline ERGN & 3855071.663 & 3207162.247 & 3929594.538 \\
\hline MALY & 3936259.3414 & 3099410.1646 & 3935525.4066 \\
\hline SIV1 & 3906623.5203 & 3200003.0214 & 3884299.1766 \\
\hline
\end{tabular}

Tablo 3. OPUS servisinde seçilen 3 adet IGS istasyonuna ait bilgiler

\begin{tabular}{cccccc}
\hline Nokta & Ülke & Şehir & Enlem $\left(^{\circ}\right)$ & Boylam $\left(^{\circ}\right)$ & Yükseklik (m) \\
\hline BSHM & İsrail & Haifa & 35.0200000 & 32.7788889 & 225.1 \\
\hline NICO & Nicosia & Kibris & 33.3963889 & 35.1408333 & 155.0 \\
\hline ZECK & Zelenchukskaya & Rusya & 43.7883908 & 41.5650674 & 1166.8 \\
\hline
\end{tabular}




\section{ELAZ}

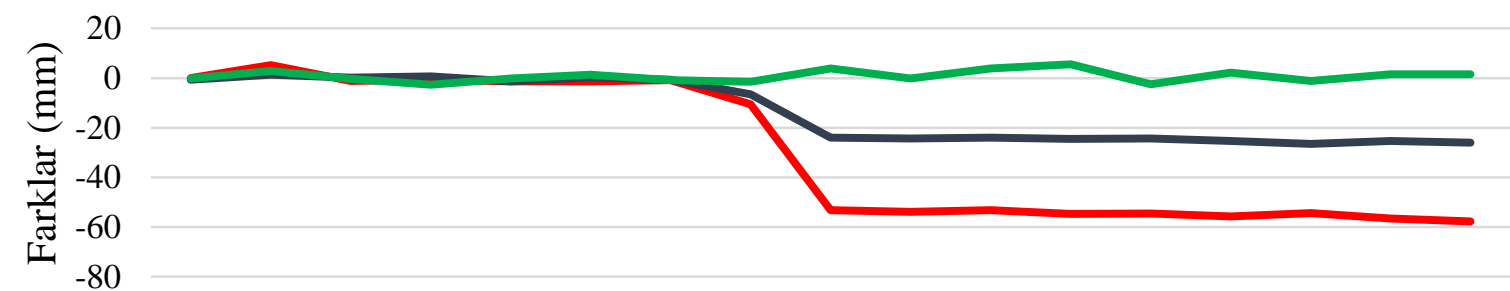

\begin{tabular}{|c|c|c|c|c|c|c|c|c|c|c|c|c|c|c|c|c|}
17.1 & 18.1 & 19.1 & 20.1 & 21.1 & 22.1 & 23.1 & 24.1 & 25.1 & 26.1 & 27.1 & 28.1 & 29.1 & 30.1 & 31.1 & 1.2 & 2.2
\end{tabular}

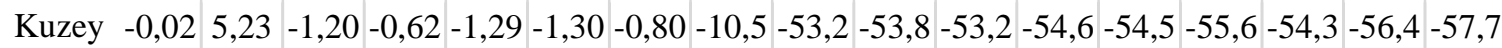

\begin{tabular}{lllllll|lllllllllll} 
Doğu & $-0,62$ & 1,42 & 0,15 & 0,64 & $-1,26$ & 0,29 & $-0,62$ & $-6,46$ & $-23,9$ & $-24,2$ & $-23,9$ & $-24,4$ & $-24,3$ & $-25,3$ & $-26,4$ & $-25,3$ & $-26,0$
\end{tabular}

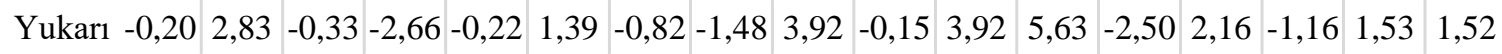

Günler

$\longrightarrow$ Kuzey Doğu $\longrightarrow$ Yukarı

Şekil 6. OPUS servisi ile değerlendirilen ELAZ istasyonu için hesaplanan yer değişim grafiği

\section{ERGN}

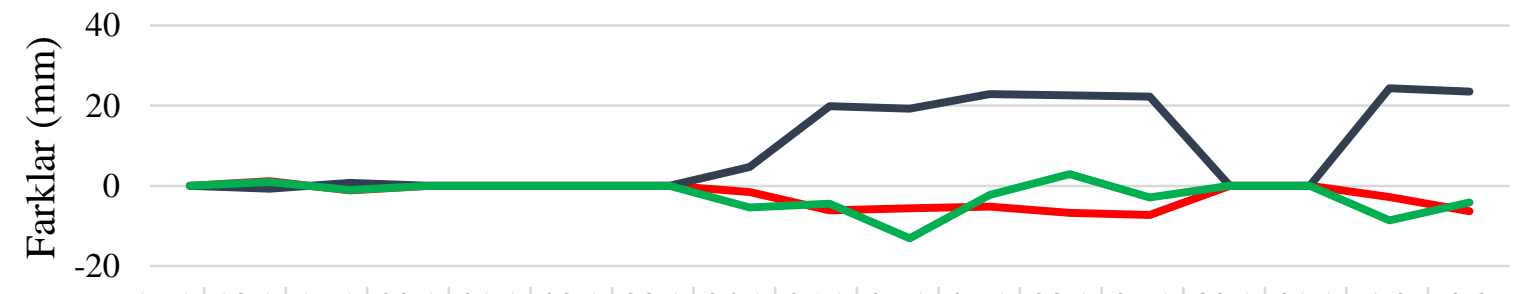

\begin{tabular}{|l|l|l|l|l|l|l|l|l|l|l|l|l|l|l|l|l|}
17.1 & 18.1 & 19.1 & 20.1 & 21.1 & 22.1 & 23.1 & 24.1 & 25.1 & 26.1 & 27.1 & 28.1 & 29.1 & 30.1 & 31.1 & 1.2 & 2.2 \\
\hline
\end{tabular}

\begin{tabular}{ll|l|l|l|l|l|l|l|l|l|l|l|l|l|l|l|l} 
Kuzey & 0,00 & 1,14 & $-1,14$ & 0,00 & 0,00 & 0,00 & 0,00 & $-1,51$ & $-6,08$ & $-5,64$ & $-5,22$ & $-6,74$ & $-7,26$ & 0,00 & 0,00 & $-2,74$ & $-6,31$
\end{tabular}

\begin{tabular}{lll|l|l|l|l|l|l|l|l|l|l|l} 
Doğu & 0,00 & $-0,70$ & 0,70 & 0,00 & 0,00 & 0,00 & 0,00 & 4,67 & 19,91 & $19,2622,8622,6022,22$ & 0,00 & 0,00 & $24,3923,50$
\end{tabular}

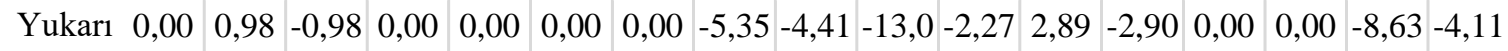

Yukarı

$\longrightarrow$ Kuzey Doğu $\longrightarrow$ Yukarı

Şekil 7. OPUS servisi ile değerlendirilen ERGN istasyonu için hesaplanan yer değişim grafiği 


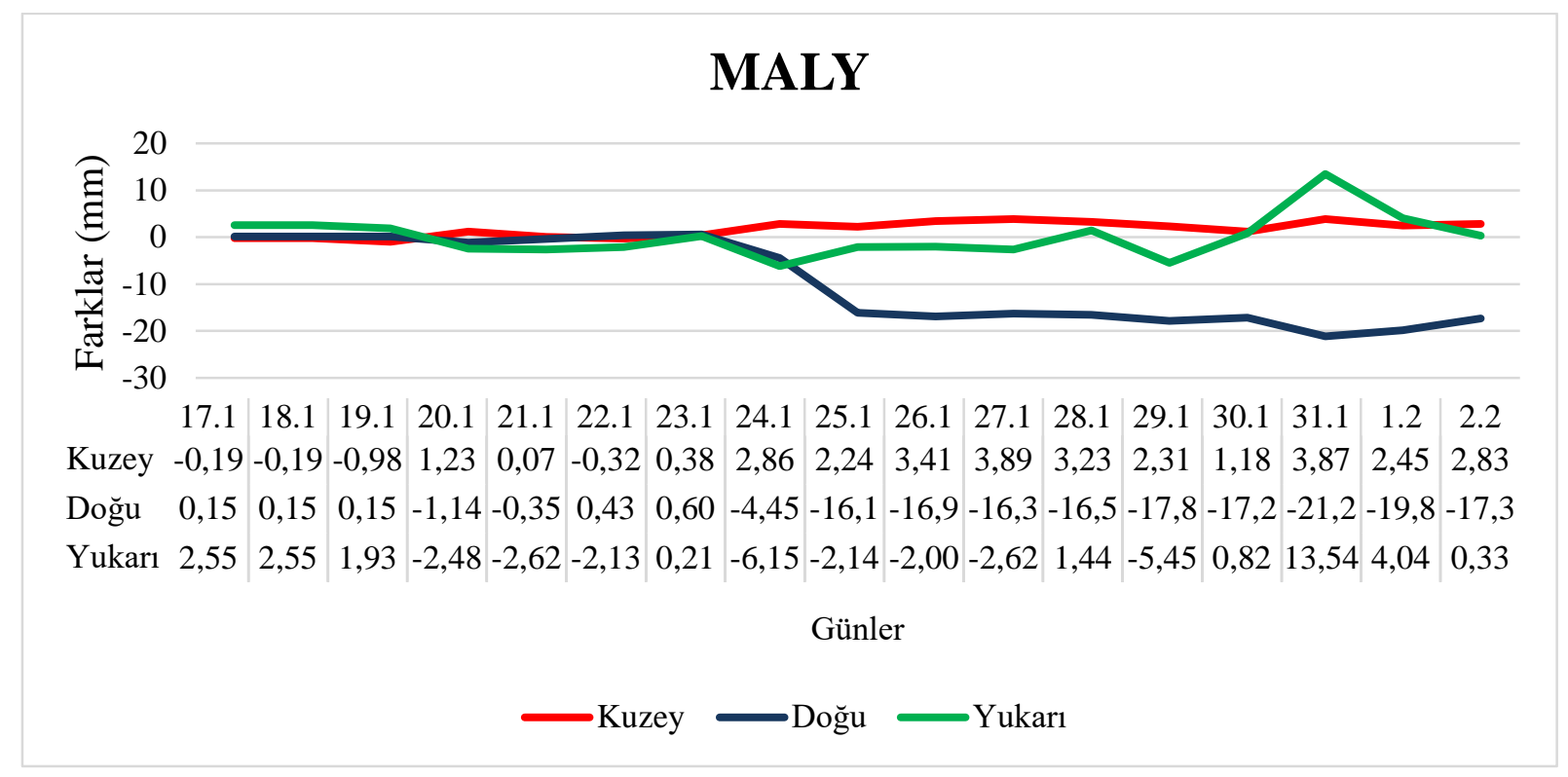

Şekil 8. OPUS servisi ile değerlendirilen MALY istasyonu için hesaplanan yer değişim grafiği

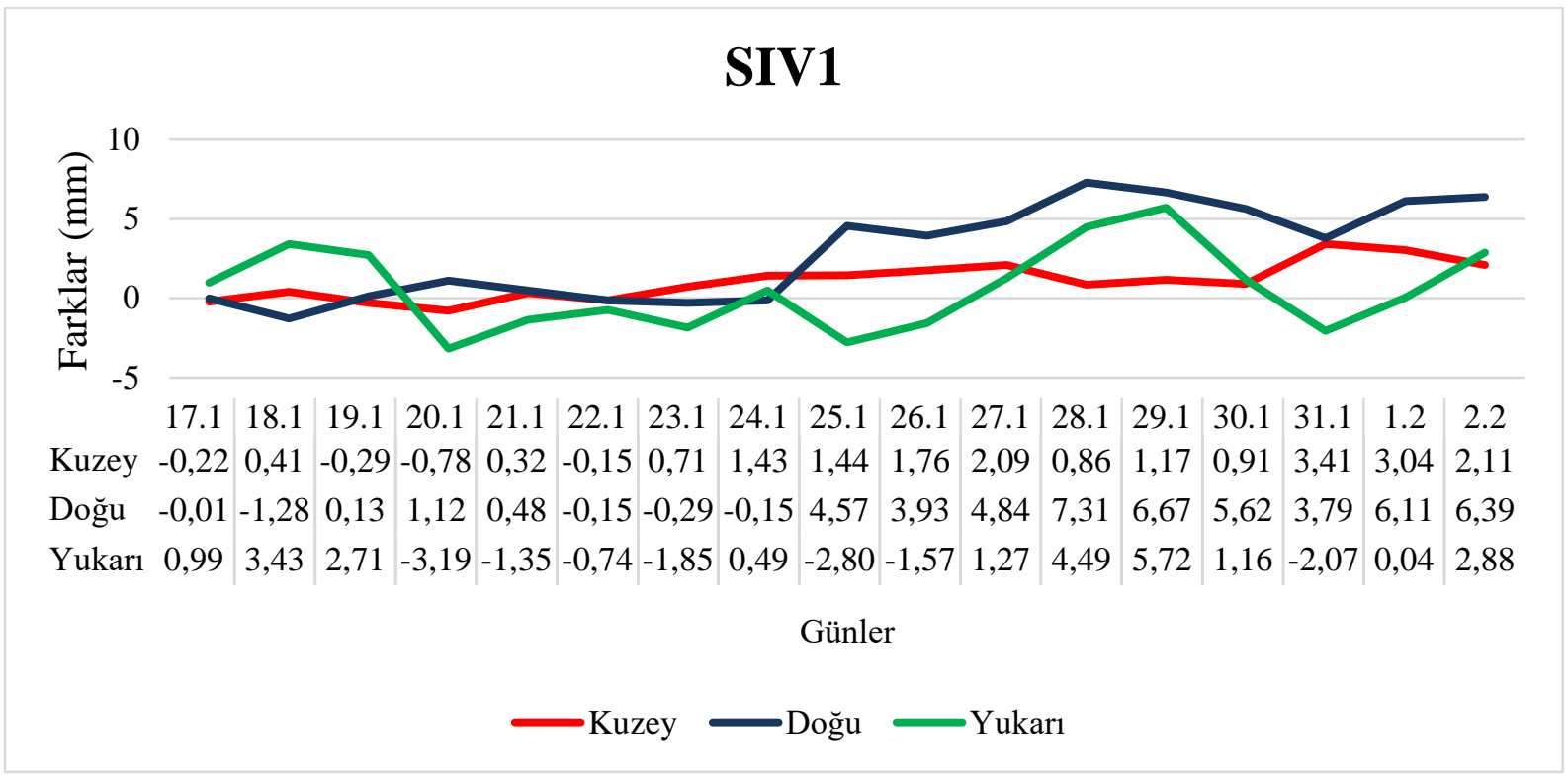

Şekil 9. OPUS servisi ile değerlendirilen SIV1 istasyonu için hesaplanan yer değişim grafiği 
Tablo 4. ELAZ TUSAGA-Aktif istasyonunun deprem öncesi yer değiştirmelerinin standart sapmasına göre deprem sonrası deformasyonların miktarları (OPUS)

\begin{tabular}{ccccccc}
\hline Tarih & $\begin{array}{c}\text { Kuzey } \\
(\mathbf{m m})\end{array}$ & $\begin{array}{c}\text { Doğu } \\
(\mathbf{m m})\end{array}$ & $\begin{array}{c}\text { Yukarı } \\
(\mathbf{m m})\end{array}$ & $\begin{array}{c}\text { Karar } \\
\text { Kuzey } \\
(\mathbf{m m})\end{array}$ & $\begin{array}{c}\text { Karar } \\
\text { Doğu } \\
(\mathbf{m m})\end{array}$ & $\begin{array}{c}\text { Karar } \\
\text { Yukarı } \\
(\mathbf{m m})\end{array}$ \\
\hline $\mathbf{2 4 . 0 1 . 2 0 2 0}$ & -10.53 & -6.46 & -1.48 & + & + & - \\
\hline $\mathbf{2 5 . 0 1 . 2 0 2 0}$ & -53.25 & -23.96 & 3.92 & + & + & - \\
\hline $\mathbf{2 6 . 0 1 . 2 0 2 0}$ & -53.84 & -24.24 & -0.15 & + & + & - \\
\hline $\mathbf{2 7 . 0 1 . 2 0 2 0}$ & -53.25 & -23.96 & 3.92 & + & + & - \\
\hline $\mathbf{2 8 . 0 1 . 2 0 2 0}$ & -54.62 & -24.45 & 5.63 & + & + & + \\
\hline $\mathbf{2 9 . 0 1 . 2 0 2 0}$ & -54.52 & -24.39 & -2.50 & + & + & - \\
\hline $\mathbf{3 0 . 0 1 . 2 0 2 0}$ & -55.68 & -25.37 & 2.16 & + & + & - \\
\hline $\mathbf{3 1 . 0 1 . 2 0 2 0}$ & -54.31 & -26.43 & -1.16 & ++ & + & - \\
\hline $\mathbf{0 1 . 0 2 . 2 0 2 0}$ & -56.47 & -25.37 & 1.53 & + & + & - \\
\hline $\mathbf{0 2 . 0 2 . 2 0 2 0}$ & -57.73 & 26.00 & 1.52 & + & + & - \\
\hline
\end{tabular}

Tablo 4' e göre ELAZ TUSAGA-Aktif istasyonunda deprem sonrası tüm günlerde Kuzey ve Doğu yönlerinde hareketler anlamlı çıkmıştır. Kuzey yöndeki hareket miktarının yaklaşık $-58 \mathrm{~mm}$ ile $-53 \mathrm{~mm}$ arasında, Doğu yönündeki hareket miktarının ise yaklaşık $-27 \mathrm{~mm}$ ile $-23 \mathrm{~mm}$ arasında olduğu belirlenmiştir. $\mathrm{Bu}$ istasyonda Kuzey ve Doğu yönlerinde ilk hareket, deprem günü 24 Ocakta başlamış, 2 Şubat gününe kadar devam etmiştir. Kuzey ve Doğu yönündeki hareketlerin yönü aynı ve deformasyon büyüklüklerinin birbirine yakın olduğu görülmektedir. Yukarı yönde yalnızca Ocak ayının 28. gününde yaklaşık 5 mm' lik bir hareket anlamlı çıkmıştır. Yukarı yönlü hareketlerin genel olarak kendi içinde tutarsiz olduğu, yönlerinin ve büyüklüklerinin farklı olduğu görülmektedir.

Tablo 5' e göre ERGN TUSAGA-Aktif istasyonunda deprem sonrası bazı günlerde Kuzey ve Doğu yönlerinde hareketler anlamlı çıkmıştır. Kuzey yöndeki hareket miktarının yaklaşık -5 mm ile -7 mm, Doğu yönündeki hareket miktarının ise yaklaşık $20 \mathrm{~mm}$ ile $25 \mathrm{~mm}$ arasında olduğu belirlenmiştir. $\mathrm{Bu}$ istasyonda Kuzey ve Doğu yönündeki ilk atım 24 Ocak günü başlamış, 2 Şubat gününe kadar devam etmiştir. Hareketlerin yönünün aynı ve deformasyon büyüklüklerinin birbirine yakın olduğu görülmektedir. Yukarı yönde ise belirlenen hareket miktarları yaklaşık -4 mm ile $-13 \mathrm{~mm}$ arasında ve anlamlı olarak tespit edilmiştir. Ocak ayının 29. günündeki anlamsız çıkan hareketin yönünün diğer günlere göre ters yönlü olduğu görülmektedir.

Tablo 6' ya göre MALY TUSAGA-Aktif istasyonunda deprem sonrası tüm günlerde Kuzey ve Doğu yönündeki hareketler anlamlı çıkmıştır. Kuzey yöndeki hareket miktarı yaklaşık $1 \mathrm{~mm}$ ile $4 \mathrm{~mm}$ arasında, Doğu yönündeki hareket miktarı ise yaklaşık $\quad-4$ ile $\quad-21 \quad \mathrm{~mm}$ arasında değişmektedir. Bu istasyonda Kuzey ve 
Doğu yönündeki ilk atım 24 Ocak günü başlamış, 2 Şubat gününe kadar devam etmiştir. Hareketlerin yönünün aynı ve deformasyon büyüklüklerinin birbirine yakın olduğu görülmektedir. Doğu yönündeki hareketlerin deprem gününden itibaren 31 Ocak gününe kadar sistematik bir biçimde arttı̆ğ görülmektedir. Yukarı yönde yalnızca Ocak ayının 31. gününde yaklaşık 13.5 mm' lik bir hareket anlamlı olarak belirlenmiştir.

Tablo 5. ERGN TUSAGA-Aktif istasyonunun deprem öncesi yer değiştirmelerinin standart sapmasına göre deprem sonrası deformasyonlarının miktarları (OPUS)

\begin{tabular}{ccccccc}
\hline Tarih & $\begin{array}{c}\text { Kuzey } \\
(\mathbf{m m})\end{array}$ & $\begin{array}{c}\text { Doğu } \\
(\mathbf{m m})\end{array}$ & $\begin{array}{c}\text { Yukari } \\
(\mathbf{m m})\end{array}$ & $\begin{array}{c}\text { Karar } \\
\text { Kuzey } \\
(\mathbf{m m})\end{array}$ & $\begin{array}{c}\text { Karar } \\
\text { Doğu } \\
(\mathbf{m m})\end{array}$ & $\begin{array}{c}\text { Karar } \\
\text { Yukarı } \\
(\mathbf{m m})\end{array}$ \\
\hline $\mathbf{2 4 . 0 1 . 2 0 2 0}$ & -1.51 & 4.67 & -5.35 & - & + & + \\
\hline $\mathbf{2 5 . 0 1 . 2 0 2 0}$ & -6.08 & 19.91 & -4.41 & + & + & + \\
\hline $\mathbf{2 6 . 0 1 . 2 0 2 0}$ & -5.64 & 19.26 & -13.03 & + & + & + \\
\hline $\mathbf{2 7 . 0 1 . 2 0 2 0}$ & -5.22 & 22.86 & -2.27 & + & + & - \\
\hline $\mathbf{2 8 . 0 1 . 2 0 2 0}$ & -6.74 & 22.60 & 2.89 & + & + & - \\
\hline $\mathbf{2 9 . 0 1 . 2 0 2 0}$ & -7.26 & 22.22 & -2.90 & + & + & - \\
\hline $\mathbf{3 0 . 0 1 . 2 0 2 0}$ & & & & & & + \\
\hline $\mathbf{3 1 . 0 1 . 2 0 2 0}$ & & & & & + & + \\
\hline $\mathbf{0 1 . 0 2 . 2 0 2 0}$ & -2.74 & 24.39 & -8.63 & - & + & + \\
\hline $\mathbf{0 2 . 0 2 . 2 0 2 0}$ & -6.31 & 23.50 & -4.11 & + & + & + \\
\hline
\end{tabular}

Tablo 6. MALY TUSAGA-Aktif istasyonunun deprem öncesi yer değiştirmelerinin standart sapmasına göre deprem sonrası deformasyonlarının miktarları (OPUS)

\begin{tabular}{ccccccc}
\hline Tarih & $\begin{array}{c}\text { Kuzey } \\
(\mathbf{m m})\end{array}$ & $\begin{array}{c}\text { Doğu } \\
(\mathbf{m m})\end{array}$ & $\begin{array}{c}\text { Yukarı } \\
(\mathbf{m m})\end{array}$ & $\begin{array}{c}\text { Karar } \\
\text { Kuzey } \\
(\mathbf{m m})\end{array}$ & $\begin{array}{c}\text { Karar } \\
\text { Doğu } \\
(\mathbf{m m})\end{array}$ & $\begin{array}{c}\text { Karar } \\
\text { Yukarı } \\
(\mathbf{m m})\end{array}$ \\
\hline $\mathbf{2 4 . 0 1 . 2 0 2 0}$ & 2.86 & -4.45 & -6.15 & + & + & - \\
\hline $\mathbf{2 5 . 0 1 . 2 0 2 0}$ & 2.24 & -16.13 & -2.14 & + & + & - \\
\hline $\mathbf{2 6 . 0 1 . 2 0 2 0}$ & 3.41 & -16.92 & -2.00 & + & + & - \\
\hline $\mathbf{2 7 . 0 1 . 2 0 2 0}$ & 3.89 & -16.30 & -2.62 & + & + & - \\
\hline $\mathbf{2 8 . 0 1 . 2 0 2 0}$ & 3.23 & -16.58 & 1.44 & + & + & - \\
\hline $\mathbf{2 9 . 0 1 . 2 0 2 0}$ & 2.31 & -17.87 & -5.45 & + & + & - \\
\hline $\mathbf{3 0 . 0 1 . 2 0 2 0}$ & 1.18 & -17.20 & 0.82 & + & + & - \\
\hline $\mathbf{3 1 . 0 1 . 2 0 2 0}$ & 3.87 & -21.20 & 13.54 & + & + & + \\
\hline $\mathbf{0 1 . 0 2 . 2 0 2 0}$ & 2.45 & -19.84 & 4.04 & + & + & - \\
\hline $\mathbf{0 2 . 0 2 . 2 0 2 0}$ & 2.83 & -17.37 & -0.33 & + & + & - \\
\hline
\end{tabular}


Tablo 7' ye göre SIV1 TUSAGA-Aktif istasyonunda deprem sonrası bazı günlerde Kuzey ve Doğu yönlerindeki hareketler anlamlı çıkmıştır. Doğu yönünde 24 Ocak günü hariç diğer tüm günlerdeki hareketler anlamlı çıkmıştır. Kuzey yöndeki hareket miktarı yaklaşık $1.7 \mathrm{~mm}$ ile $3.4 \mathrm{~mm}$ arasında, Doğu yönündeki hareket miktarı ise yaklaşı $1 \mathrm{k} .8 \mathrm{~mm}$ ile $7.3 \mathrm{~mm}$ arasında değişmektedir. $\mathrm{Bu}$ istasyonda Doğu yönündeki ilk atım 25 Ocak günü başlamış, 2 Şubat gününe kadar devam etmiştir. Hareketlerin yönü aynı ve deformasyon büyüklüklerinin birbirine yakın olduğu görülmektedir. Yukarı yönde yalnızca Ocak ayının 29. gününde yaklaşık $6 \mathrm{~mm}$ ' lik hareket belirlenmesine rağmen, bu gün dâhil diğer tüm günlerde meydana gelen hareketler anlamlı olarak tespit edilememiştir. 25 Ocak günü için hesaplanan TUSAGA-Aktif istasyonların toposentrik koordinatlarına göre yatay ve yukarı yönlü hareketleri sırasıyla Şekil 10 ve Şekil 11' de çizilmiştir. Yatay deformasyon vektörleri aşağıdaki eşitlikten hesaplanmıştır.

$$
Y . D . V .=\sqrt{\Delta K u z e y^{2}+\Delta D o g ̆ u^{2}}
$$

Tablo 7. SIV1 TUSAGA-Aktif istasyonunun deprem öncesi yer değiştirmelerinin standart sapmasına göre deprem sonrası deformasyonlarının miktarları (OPUS)

\begin{tabular}{ccccccc}
\hline Tarih & $\begin{array}{c}\text { Kuzey } \\
(\mathbf{m m})\end{array}$ & $\begin{array}{c}\text { Doğu } \\
(\mathbf{m m})\end{array}$ & $\begin{array}{c}\text { Yukarı } \\
(\mathbf{m m})\end{array}$ & $\begin{array}{c}\text { Karar } \\
\text { Kuzey } \\
(\mathbf{m m})\end{array}$ & $\begin{array}{c}\text { Karar } \\
\text { Doğu } \\
(\mathbf{m m})\end{array}$ & $\begin{array}{c}\text { Karar } \\
\text { Yukarı } \\
(\mathbf{m m})\end{array}$ \\
\hline $\mathbf{2 4 . 0 1 . 2 0 2 0}$ & 1.43 & -0.15 & 0.49 & - & - & - \\
\hline $\mathbf{2 5 . 0 1 . 2 0 2 0}$ & 1.44 & 4.57 & -2.80 & - & + & - \\
\hline $\mathbf{2 6 . 0 1 . 2 0 2 0}$ & 1.76 & 3.93 & -1.57 & + & + & - \\
\hline $\mathbf{2 7 . 0 1 . 2 0 2 0}$ & 2.09 & 4.84 & 1.27 & + & + & - \\
\hline $\mathbf{2 8 . 0 1 . 2 0 2 0}$ & 0.86 & 7.31 & 4.49 & - & + & - \\
\hline $\mathbf{2 9 . 0 1 . 2 0 2 0}$ & 1.17 & 6.67 & 5.72 & - & + & - \\
\hline $\mathbf{3 0 . 0 1 . 2 0 2 0}$ & 0.91 & 5.62 & 1.16 & - & + & - \\
\hline $\mathbf{3 1 . 0 1 . 2 0 2 0}$ & 3.41 & 3.79 & -2.07 & + & + & - \\
\hline $\mathbf{0 1 . 0 2 . 2 0 2 0}$ & 3.04 & 6.11 & 0.04 & + & + & - \\
\hline $\mathbf{0 2 . 0 2 . 2 0 2 0}$ & 2.11 & 6.39 & 2.88 & + & + & - \\
\hline
\end{tabular}




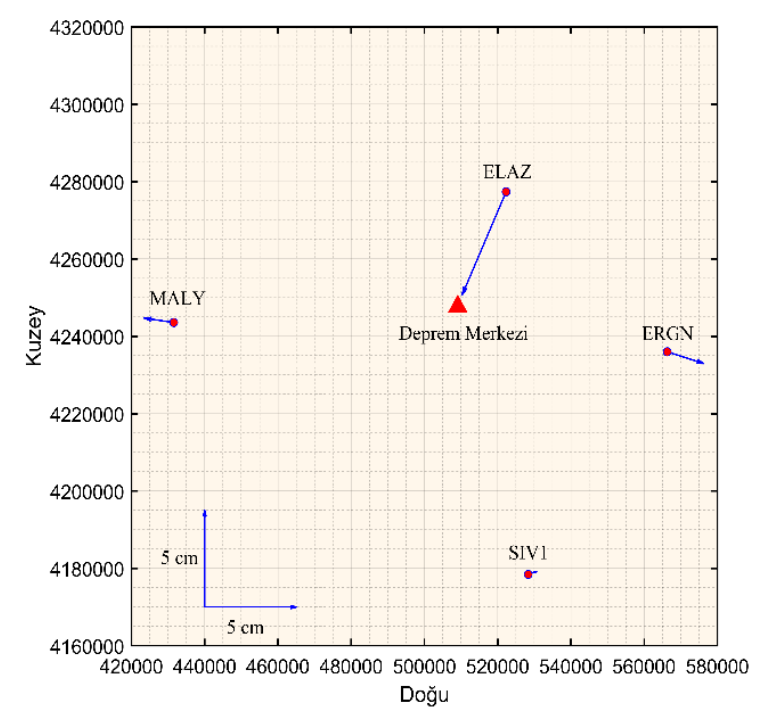

Şekil 10. TUSAGA-Aktif istasyonlarının OPUS ile belirlenmiş 25 Ocak 2020 tarihli yatay hareketleri

\subsection{AUSPOS ile yapılan değerlendirme sonuçları}

AUSPOS değerlendirme servisi ile ilk yedi güne ait elde edilen kartezyen koordinatların aritmetik ortalama koordinat değerleri Tablo 8' de verilmektedir. $\mathrm{Bu}$

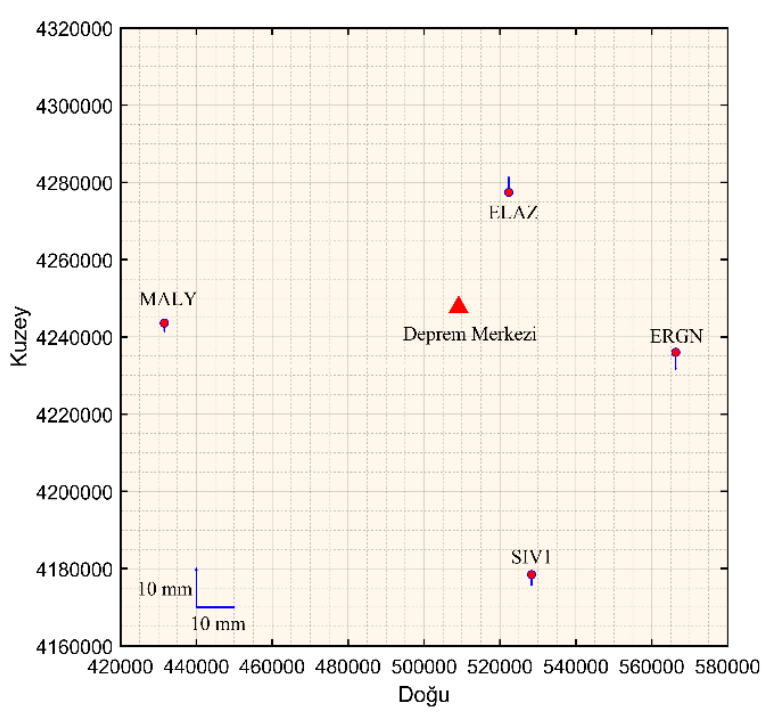

Şekil 11. TUSAGA-Aktif istasyonlarının OPUS ile belirlenmiș 25 Ocak 2020 tarihli yukarı yönlü hareketler

serviste ERGN istasyonunda, referans olarak kullanılacak ilk 7 günün tümü için değerlendirme sonuçları elde edilebilmiştir.

AUSPOS değerlendirme servisinde kullanılan 12 adet sabit IGS noktasina ait detaylar Tablo 9' da verilmektedir

Tablo 8. Çalışma kapsamında deformasyon araştırması için kullanılan TUSAGA-Aktif istasyonlarının AUSPOS değerlendirme servisi ile elde edilen koordinatlarının aritmetik ortalama değerleri

\begin{tabular}{cccc}
\hline $\begin{array}{c}\text { TUSAGA-Aktif } \\
\text { İstasyon Kodu }\end{array}$ & X (m) & Y (m) & Z (m) \\
\hline ELAZ & 3862978.8276 & 3156913.2560 & 3962227.0913 \\
\hline ERGN & 3855071.6570 & 3207162.2411 & 3929594.5341 \\
\hline MALY & 3936259.3387 & 3099410.1609 & 3935525.4053 \\
\hline SIV1 & 3906623.5204 & 3200003.0177 & 3884299.1754 \\
\hline
\end{tabular}


Tablo 9. AUSPOS servisinde seçilen 12 adet IGS istasyonuna ait bilgiler

\begin{tabular}{cccccc}
\hline Nokta & Ülke & Şehir & Enlem $\left(^{\circ}\right)$ & Boylam $\left(^{\circ}\right)$ & Yükseklik \\
\hline ANKR & Türkiye & Ankara & 39.8875116 & 32.7585789 & 974.8 \\
\hline BHR4 & Bahreyn & Manama & 26.2091413 & 50.6081455 & -13.9 \\
\hline BUCU & Romanya & Bükreş & 44.4639438 & 26.1257383 & 143.2 \\
\hline DRAG & İsrail & Metzoki & 31.5932005 & 35.3920703 & 31.8 \\
\hline GLSV & Ukrayna & Kiev & 50.3641784 & 30.4967393 & 226.8 \\
\hline ISER & Irak & Erbil & 36.1598537 & 44.0109389 & 431.3 \\
\hline ISNA & Irak & Bağdat & 33.3414143 & 44.4384019 & 72.4 \\
\hline POLV & İtalya & Matera & 40.6490615 & 16.7045454 & 534.5 \\
\hline RAMO & İsrail & Mitzpe & 30.5977596 & 34.7631400 & 893.1 \\
\hline SOFI & Bulgaristan & Sofya & 42.5560925 & 23.3947288 & 1119.6 \\
\hline TEHN & İran & Tahran & 35.6972813 & 51.3340918 & 1194.6
\end{tabular}

\section{ELAZ}

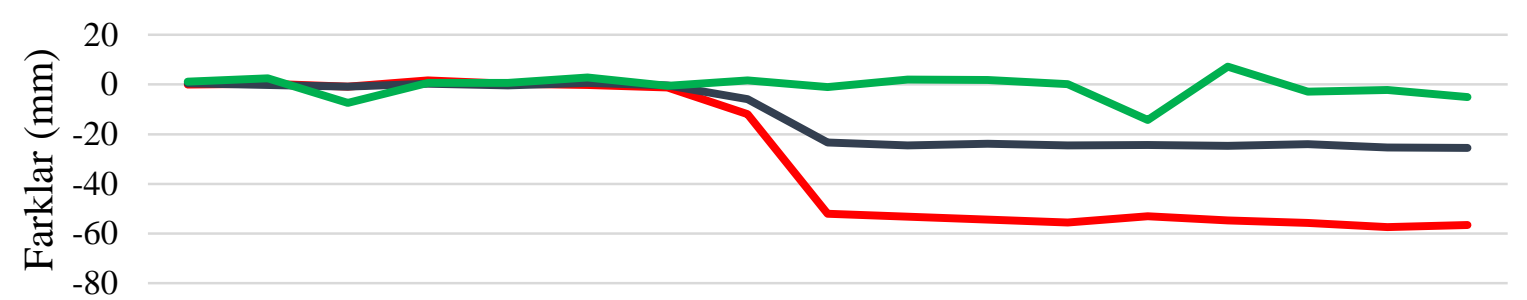

\begin{tabular}{|l|l|l|l|l|l|l|l|l|l|l|l|l|l|l|l|l|}
17.1 & 18.1 & 19.1 & 20.1 & 21.1 & 22.1 & 23.1 & 24.1 & 25.1 & 26.1 & 27.1 & 28.1 & 29.1 & 30.1 & 31.1 & 1.2 & 2.2
\end{tabular}

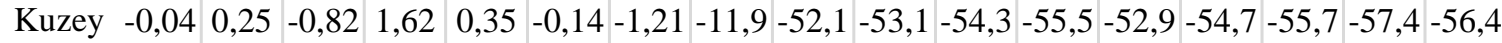
$\begin{array}{llllllllllllllllll}\text { Doğu } & 0,50 & -0,13 & -0,84 & 0,36 & -0,27 & 0,64 & -0,27 & -5,82 & -23,4 & -24,5 & -23,7 & -24,5 & -24,3 & -24,7 & -24,0 & -25,3 & -25,5\end{array}$

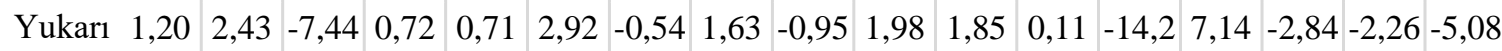
Günler $\longrightarrow$ Kuzey Doğu $\longrightarrow$ Yukarı

Şekil 12. AUSPOS servisi ile değerlendirilen ELAZ istasyonu için hesaplanan yer değişim grafiği 


\section{ERGN}

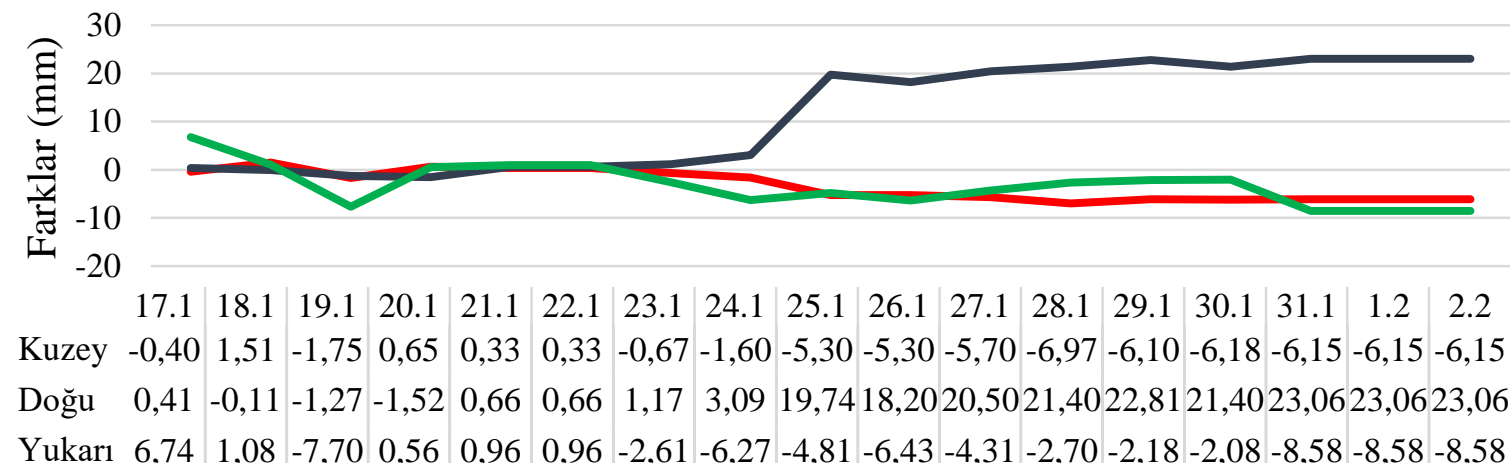

Günler

$\longrightarrow$ Kuzey Doğu $\longrightarrow$ Yukarı

Şekil 13. AUSPOS servisi ile değerlendirilen ERGN istasyonu için hesaplanan yer değişim grafiği

\section{MALY}

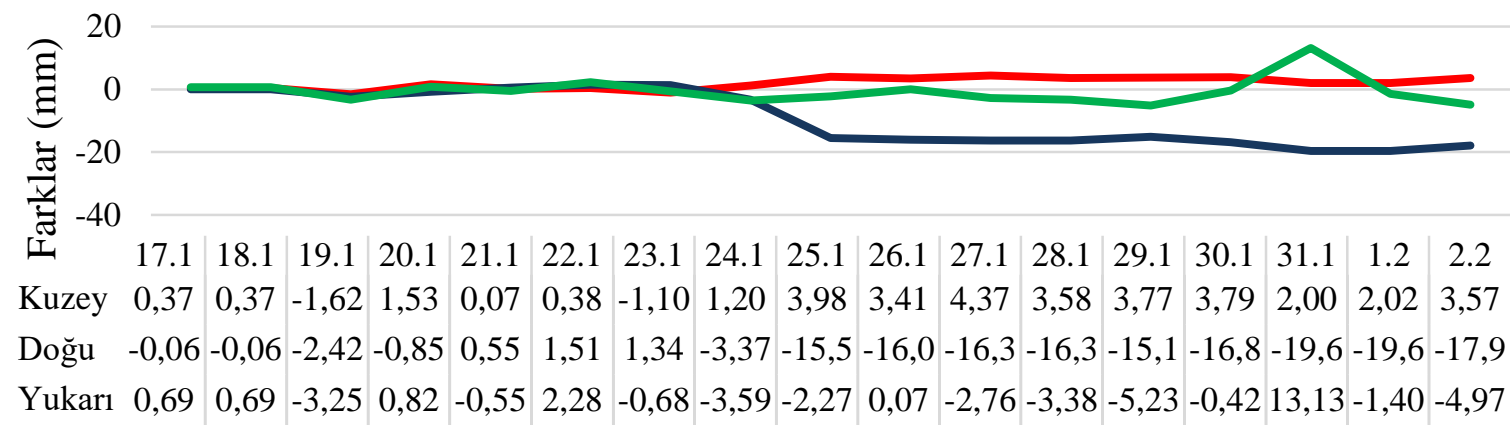

Günler

$\longrightarrow$ Kuzey Doğu $\longrightarrow$ Yukarı

Şekil 14. AUSPOS servisi ile değerlendirilen MALY istasyonu için hesaplanan yer değişim grafiği 


\section{SIV1}

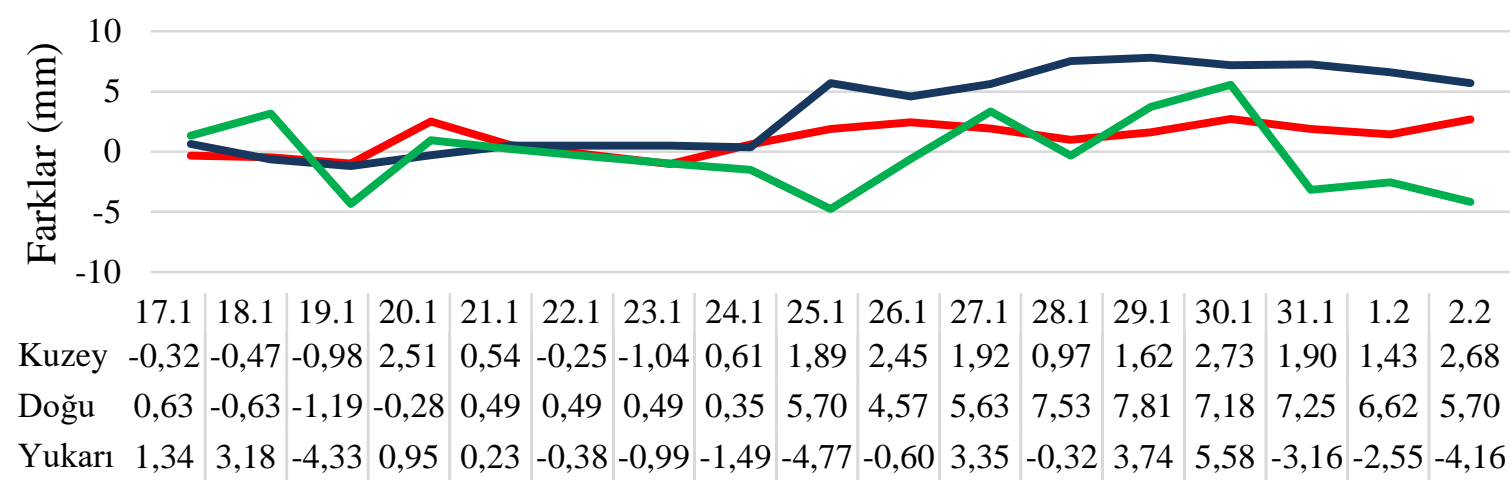

Günler

Kuzey Doğu $\longrightarrow$ Yukarı

Şekil 15. AUSPOS servisi ile değerlendirilen SIV1 istasyonu için hesaplanan yer değiş̧im grafiği

AUSPOS değerlendirme servisi ile elde edilen ELAZ, ERGN, MALY ve SIV1 kodlu TUSAGA-Aktif istasyonlarının yer değişim grafikleri şekil 12, 13, 14 ve $15^{\prime}$ de ayrı ayrı verilmiştir.

Sivrice-Elazı $\breve{g}$ depreminden kaynaklanan deformasyonları belirlemek için deprem tarihinden sonraki 7 gün için, AUSPOS servisi ile değerlendirilmiş tüm yönlere ait standart sapma değerlerinin 3 katını geçen deformasyon miktarları Tablo 10' da verilmiştir. Tablo 10' a göre ELAZ TUSAGA-Aktif istasyonunda deprem sonrası tüm günlerde Kuzey ve Doğu yönlerinde hareketler anlamlı çıkmıştır. Kuzey yöndeki hareket miktarı yaklaşık -52 $\mathrm{mm}$ ile $58 \mathrm{~mm}$, Doğu yönündeki hareket miktarı yaklaşık $-23 \mathrm{~mm}$ ile $-26 \mathrm{~mm}$ arasında belirlenmiştir. $\mathrm{Bu}$ istasyonda Kuzey ve Doğu yönlerinde ilk hareket deprem günü 24 Ocakta başlamış, 2 Şubat gününe kadar devam etmiştir. Kuzey ve Doğu yönündeki hareketlerin yönü aynı ve deformasyon büyüklüklerinin birbirine yakın olduğu görülmektedir. Yukarı yönde yalnızca Ocak ayının 28. gününde yaklaşık -14 mm' lik bir hareket anlamlı olarak tespit edilmiştir. Yukarı yönlü hareketlerin genel olarak kendi içinde tutarsız olduğu ve aynı zamanda yönleri ile büyüklüklerinin farklı olduğu görülmektedir.

Tablo 11' e göre ERGN TUSAGA-Aktif istasyonunda deprem sonrası 24 Ocak günü hariç diğer tüm günlerde Kuzey ve Doğu yönündeki hareketleri anlamlı çıkmıştır. Kuzey yöndeki hareket miktarının yaklaşık $-7 \mathrm{~mm}$ ile $-5.3 \mathrm{~mm}$ arasında, Doğu yönündeki hareket miktarı ise yaklaşı 18 $\mathrm{mm}$ ile $23 \mathrm{~mm}$ arasinda olduğu belirlenmiştir. $\mathrm{Bu}$ istasyonda Kuzey ve Doğu yönündeki ilk atım 24 Ocak günü başlamış, 2 Şubat gününe kadar devam etmiştir. Hareketlerin yönü aynı ve deformasyon büyüklüklerinin birbirine yakın olduğu görülmektedir. Doğu yönlü hareketlerin deprem gününden itibaren sistematik bir biçimde arttı̆̆ görülmektedir. Yukarı yönlü hareketlerin 30 Ocak gününe kadar azaldığı, 31 Ocak gününden sonrada yaklaşık 6 mm' lik bir 
atım yaptığı belirlenmiştir. Yukarı yönde ise hareket miktarlarının yaklaşık 8 mm' ye kadar çıkmasının anlamsız olduğu belirlenmiştir.

Tablo 10. ELAZ TUSAGA-Aktif istasyonunun deprem öncesi yer değiştirmelerinin standart sapmasına göre deprem sonrası deformasyonların miktarları (AUSPOS)

\begin{tabular}{ccccccc}
\hline Tarih & $\begin{array}{c}\text { Kuzey } \\
(\mathbf{m m})\end{array}$ & $\begin{array}{c}\text { Doğu } \\
(\mathbf{m m})\end{array}$ & $\begin{array}{c}\text { Yukarı } \\
(\mathbf{m m})\end{array}$ & $\begin{array}{c}\text { Karar } \\
\text { Kuzey } \\
(\mathbf{m m})\end{array}$ & $\begin{array}{c}\text { Karar } \\
\text { Doğu } \\
(\mathbf{m m})\end{array}$ & $\begin{array}{c}\text { Karar } \\
\text { Yukarı } \\
(\mathbf{m m})\end{array}$ \\
\hline $\mathbf{2 4 . 0 1 . 2 0 2 0}$ & -11.91 & -5.82 & 1.63 & + & + & - \\
\hline $\mathbf{2 5 . 0 1 . 2 0 2 0}$ & -52.10 & -23.40 & -0.95 & + & + & - \\
\hline $\mathbf{2 6 . 0 1 . 2 0 2 0}$ & -53.17 & -24.53 & 1.98 & + & + & - \\
\hline $\mathbf{2 7 . 0 1 . 2 0 2 0}$ & -54.34 & -23.75 & 1.85 & + & + & - \\
\hline $\mathbf{2 8 . 0 1 . 2 0 2 0}$ & -55.51 & -24.53 & 0.11 & + & + & - \\
\hline $\mathbf{2 9 . 0 1 . 2 0 2 0}$ & -52.98 & -24.39 & -14.26 & + & + & + \\
\hline $\mathbf{3 0 . 0 1 . 2 0 2 0}$ & -54.72 & -24.73 & 7.14 & + & + & - \\
\hline $\mathbf{3 1 . 0 1 . 2 0 2 0}$ & -55.71 & -24.03 & -2.84 & + & + & - \\
\hline $\mathbf{0 1 . 0 2 . 2 0 2 0}$ & -57.46 & -25.30 & -2.26 & + & + & - \\
\hline $\mathbf{0 2 . 0 2 . 2 0 2 0}$ & -56.48 & -25.58 & -5.08 & + & + & - \\
\hline
\end{tabular}

Tablo 11. ERGN TUSAGA-Aktif istasyonunun deprem öncesi yer değiştirmelerinin standart sapmasına göre deprem sonrası deformasyonlarının miktarları (AUSPOS)

\begin{tabular}{ccccccc}
\hline Tarih & $\begin{array}{c}\text { Kuzey } \\
(\mathbf{m m})\end{array}$ & $\begin{array}{c}\text { Doğu } \\
(\mathbf{m m})\end{array}$ & $\begin{array}{c}\text { Yukarı } \\
(\mathbf{m m})\end{array}$ & $\begin{array}{c}\text { Karar } \\
\text { Kuzey } \\
(\mathbf{m m})\end{array}$ & $\begin{array}{c}\text { Karar } \\
\text { Doğu } \\
(\mathbf{m m})\end{array}$ & $\begin{array}{c}\text { Karar } \\
\text { Yukarı } \\
(\mathbf{m m})\end{array}$ \\
\hline $\mathbf{2 4 . 0 1 . 2 0 2 0}$ & -1.60 & 3.09 & -6.27 & - & + & - \\
\hline $\mathbf{2 5 . 0 1 . 2 0 2 0}$ & -5.30 & 19.74 & -4.81 & + & + & - \\
\hline $\mathbf{2 6 . 0 1 . 2 0 2 0}$ & -5.30 & 18.20 & -6.43 & + & + & - \\
\hline $\mathbf{2 7 . 0 1 . 2 0 2 0}$ & -5.70 & 20.50 & -4.31 & + & + & - \\
\hline $\mathbf{2 8 . 0 1 . 2 0 2 0}$ & -6.97 & 21.40 & -2.70 & + & + & - \\
\hline $\mathbf{2 9 . 0 1 . 2 0 2 0}$ & -6.10 & 22.81 & -2.18 & + & + & - \\
\hline $\mathbf{3 0 . 0 1 . 2 0 2 0}$ & -6.18 & 21.40 & -2.08 & + & + & - \\
\hline $\mathbf{3 1 . 0 1 . 2 0 2 0}$ & -6.15 & 23.06 & -8.58 & + & + & - \\
\hline $\mathbf{0 1 . 0 2 . 2 0 2 0}$ & -6.15 & 23.06 & -8.58 & + & + & - \\
\hline $\mathbf{0 2 . 0 2 . 2 0 2 0}$ & -6.15 & 23.06 & -8.58 & + & + & - \\
\hline & & & & & + & + \\
\hline
\end{tabular}


Tablo 12' e göre MALY TUSAGA-Aktif istasyonunda deprem sonrası çoğu günlerde Kuzey ve Doğu yönlerindeki hareketler anlamlı çıkmıştır. Kuzey yöndeki hareket miktarı yaklaşık $3.5 \mathrm{~mm}$ ile $4.5 \mathrm{~mm}$ arasında, Doğu yönündeki hareket miktarı ise yaklaşık $-20 \mathrm{~mm}$ ile $-15 \mathrm{~mm}$ arasında değişmektedir. $\mathrm{Bu}$ istasyonda Kuzey ve Doğu yönündeki ilk atım 24 Ocak günü başlamış, 2 Şubat gününe kadar devam etmiştir. Hareketlerin yönü aynı ve deformasyon büyüklüklerinin birbirine yakın olduğu görülmektedir. Doğu yönlü hareketlerin deprem gününden itibaren 1 Şubat gününe kadar sistematik bir biçimde arttığı görülmektedir. Yukarı yönde yalnızca Ocak ayının 29. gününde yaklaşık $-5 \mathrm{~mm}$ ' lik, 31. gününde yaklaşı $13 \mathrm{~mm}$ ' lik ve Şubat ayının 2. gününde yaklaşık -5 mm' lik oluşan hareketlerin anlamlı olduğu belirlenmiştir.

Tablo 12. MALY TUSAGA-Aktif istasyonunun deprem öncesi yer değiştirmelerinin standart sapmasına göre deprem sonrası deformasyonlarının miktarları (AUSPOS)

\begin{tabular}{ccccccc}
\hline Tarih & $\begin{array}{c}\text { Kuzey } \\
(\mathbf{m m})\end{array}$ & $\begin{array}{c}\text { Doğu } \\
(\mathbf{m m})\end{array}$ & $\begin{array}{c}\text { Yukarı } \\
(\mathbf{m m})\end{array}$ & $\begin{array}{c}\text { Karar } \\
\text { Kuzey } \\
(\mathbf{m m})\end{array}$ & $\begin{array}{c}\text { Karar } \\
\text { Doğu } \\
(\mathbf{m m})\end{array}$ & $\begin{array}{c}\text { Karar } \\
\text { Yukarı } \\
(\mathbf{m m})\end{array}$ \\
\hline $\mathbf{2 4 . 0 1 . 2 0 2 0}$ & 1.20 & -3.37 & -3.59 & - & - & - \\
\hline $\mathbf{2 5 . 0 1 . 2 0 2 0}$ & 3.98 & -15.56 & -2.27 & + & + & - \\
\hline $\mathbf{2 6 . 0 1 . 2 0 2 0}$ & 3.41 & -16.01 & 0.07 & + & + & - \\
\hline $\mathbf{2 7 . 0 1 . 2 0 2 0}$ & 4.37 & -16.35 & -2.76 & + & + & - \\
\hline $\mathbf{2 8 . 0 1 . 2 0 2 0}$ & 3.58 & -16.35 & -3.38 & + & + & - \\
\hline $\mathbf{2 9 . 0 1 . 2 0 2 0}$ & 3.77 & -15.11 & -5.23 & + & + & + \\
\hline $\mathbf{3 0 . 0 1 . 2 0 2 0}$ & 3.79 & -16.80 & -0.42 & + & + & - \\
\hline $\mathbf{3 1 . 0 1 . 2 0 2 0}$ & 2.00 & -19.68 & 13.13 & - & + & + \\
\hline $\mathbf{0 1 . 0 2 . 2 0 2 0}$ & 2.02 & -19.61 & -1.40 & - & + & - \\
\hline $\mathbf{0 2 . 0 2 . 2 0 2 0}$ & 3.57 & -17.92 & -4.97 & + & + & + \\
\hline
\end{tabular}

Tablo 13' e göre SIV1 TUSAGA-Aktif istasyonunda deprem sonrası hiçbir günde Kuzey yöndeki hareket anlamlı çıkmamıştır. Doğu yönünde ise 24 Ocak günü hariç diğer tüm günlerdeki hareketler anlamlı çıkmıştır. Doğu yönündeki hareket miktarları yaklaşık 4-8 $\mathrm{mm}$ arasında değişmektedir. $\mathrm{Bu}$ istasyonda Kuzey ve Doğu yönündeki ilk atım 24 Ocak günü başlamış, 2 Şubat gününe kadar devam etmiştir. Hareketlerin yönü aynı ve deformasyon büyüklüklerinin birbirine yakın olduğu görülmektedir. Yukarı yönde yalnızca Ocak ayının 30. gününde yaklaşık $5 \mathrm{~mm}$ ' lik hareket belirlenmesine rağmen, bu gün dâhil diğer tüm günlerde meydana gelen hareketler anlamlı olarak tespit edilememiştir. 25 Ocak günü için hesaplanan TUSAGA-Aktif istasyonların toposentrik koordinatlarına göre yatay ve yukarı yönlü hareketleri sırasıyla Şekil 16 ve Şekil 17' de çizilmiştir. Yatay deformasyon vektörleri 5eşitliğinden hesaplanmıştır. 
Tablo 13. SIV1 TUSAGA-Aktif istasyonunun deprem öncesi yer değiştirmelerinin standart sapmasına göre deprem sonrası deformasyonlarının miktarları (AUSPOS)

\begin{tabular}{ccccccc}
\hline Tarih & $\begin{array}{c}\text { Kuzey } \\
(\mathbf{m m})\end{array}$ & $\begin{array}{c}\text { Doğu } \\
(\mathbf{m m})\end{array}$ & $\begin{array}{c}\text { Yukarı } \\
(\mathbf{m m})\end{array}$ & $\begin{array}{c}\text { Karar } \\
\text { Kuzey } \\
(\mathbf{m m})\end{array}$ & $\begin{array}{c}\text { Karar } \\
\text { Doğu } \\
(\mathbf{m m})\end{array}$ & $\begin{array}{c}\text { Karar } \\
\text { Yukarı } \\
(\mathbf{m m})\end{array}$ \\
\hline $\mathbf{2 4 . 0 1 . 2 0 2 0}$ & 0.61 & 0.35 & -1.49 & - & - & - \\
\hline $\mathbf{2 5 . 0 1 . 2 0 2 0}$ & 1.89 & 5.70 & -4.77 & - & + & - \\
\hline $\mathbf{2 6 . 0 1 . 2 0 2 0}$ & 2.45 & 4.57 & -0.60 & - & + & - \\
\hline $\mathbf{2 7 . 0 1 . 2 0 2 0}$ & 1.92 & 5.63 & 3.35 & - & + & - \\
\hline $\mathbf{2 8 . 0 1 . 2 0 2 0}$ & 0.97 & 7.53 & -0.32 & - & + & - \\
\hline $\mathbf{2 9 . 0 1 . 2 0 2 0}$ & 1.62 & 7.81 & 3.74 & - & + & - \\
\hline $\mathbf{3 0 . 0 1 . 2 0 2 0}$ & 2.73 & 7.18 & 5.58 & - & + & - \\
\hline $\mathbf{3 1 . 0 1 . 2 0 2 0}$ & 1.90 & 7.25 & -3.16 & - & + & - \\
\hline $\mathbf{0 1 . 0 2 . 2 0 2 0}$ & 1.43 & 6.62 & -2.55 & - & + & - \\
\hline $\mathbf{0 2 . 0 2 . 2 0 2 0}$ & 2.68 & 5.70 & -4.16 & - & + & - \\
\hline
\end{tabular}

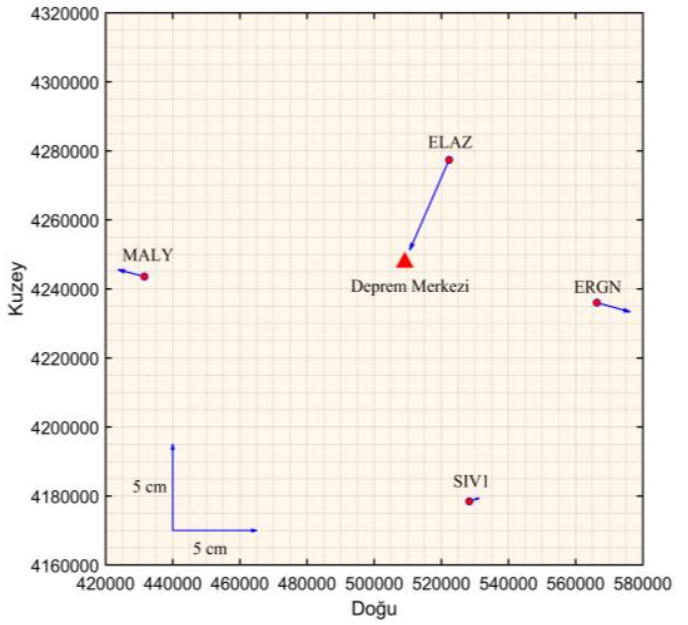

Şekil16.

TUSAGA-Aktif istasyonlarının AUSPOS ile belirlenmiş 25 Ocak 2020 tarihli yatay hareketleri

\subsection{OPUS ve AUSPOS servis sonuçlarının karşılaştırılması}

OPUS ve AUSPOS web tabanl1 servislerin ELAZ TUSAGA-Aktif istasyonu için belirlenen deformasyon

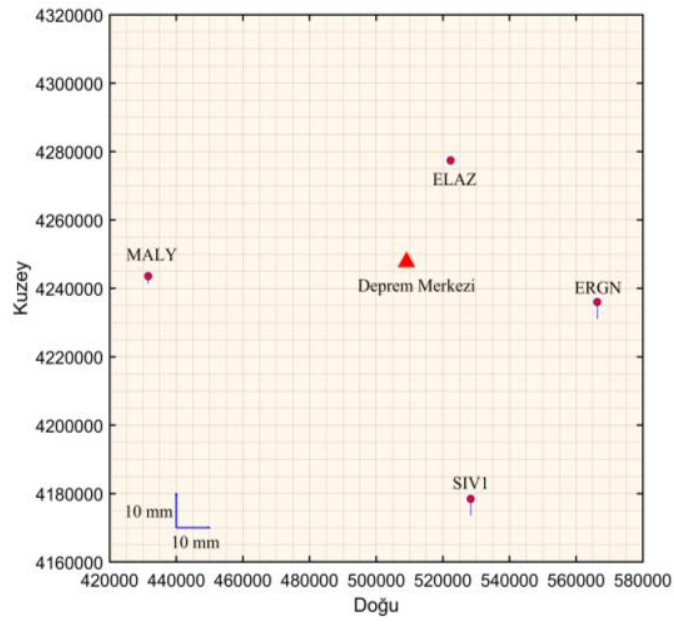

Şekil17.

TUSAGA-Aktif istasyonlarının AUSPOS ile belirlenmiş 25 Ocak 2020 tarihli yukarı yönlü hareketler

miktarları Şekil 18' de gösterilmiştir. Her iki servisten elde edilen sonuçlar karşılaştırıldığında Kuzey ve Doğu yönlerinde birbirleriyle uyumlu sonuçlar elde edilmiştir. İki servisin ELAZ TUSAGA-Aktif istasyonunda tespit edilen en büyük deformasyon değeri 29 Ocak 2020 
tarihinde OPUS servisinde $-1.5 \mathrm{~cm}$ civarında olurken, AUSPOS servisi aynı hareketi $2.5 \mathrm{~mm}$ olarak tespit etmiştir. OPUS servisinin verdiği hareket miktarı bir sonraki gün ile ters yönde $7 \mathrm{~mm}$ olması durumu OPUS servisinin değerlendirme hatasından kaynaklandığı şeklinde söylenebilir. Genel olarak değerlendirildiğinde her iki web tabanlı değerlendirme servisi tüm ELAZ TUSAGA-Aktif istasyonu için birbirlerine benzer ya da yakın sonuçlar vermiştir. Tespit edilen deformasyon yönünün Doğu Anadolu Fay Zonunun sol yanal doğrultulu fay olması ile uyuşumlu olduğu görülmektedir.

\section{ELAZ}

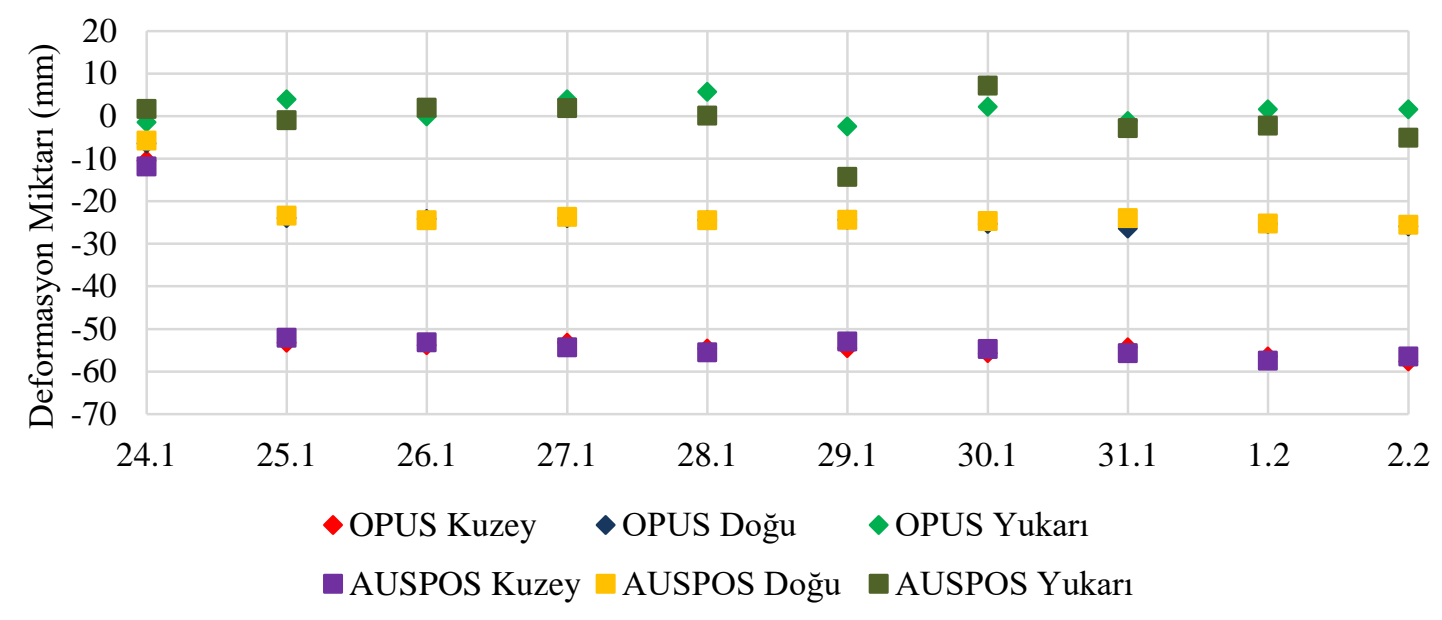

Şekil 18. TUSAGA-Aktif istasyonun deprem günü sonrası günler için deformasyon miktarları

OPUS ve AUSPOS web tabanlı servislerin ERGN TUSAGA-Aktif istasyonu için belirlenen deformasyon miktarları Şekil 19' da gösterilmiştir. Her iki servisten elde edilen sonuçlar karşılaştırıldığında Kuzey ve Doğu yönlerinde birbirleriyle uyumlu sonuçlar elde edilmiştir. İki servisin ERGN TUSAGA-Aktif istasyonunda tespit edilen en büyük konum fark1 26 Ocak 2020 tarihinde OPUS servisinde -6 mm' ye yakın olurken, AUSPOS servisi bu fark1 $-1.3 \mathrm{~cm}$ olarak tespit etmiştir. Devam eden günler incelendiğinde OPUS servisinin verdiği sonuçların daha tutarlı olduğu görülmektedir. Çünkü 13' mm' lik hareketin ardından ertesi günde yaklaşık 2' $\mathrm{mm}$ lik bir hareket tespit edilmiştir. Ertesi gün ile arasında $1 \mathrm{~cm}$ ' ye yakın fark olmasindan dolayı AUSPOS servisinin vermiş olduğu sonuç hatalı olarak değerlendirilebilir. $\quad \mathrm{Bu}$ durum değerlendirme servisi hatası olarak kabul edilebilir. 


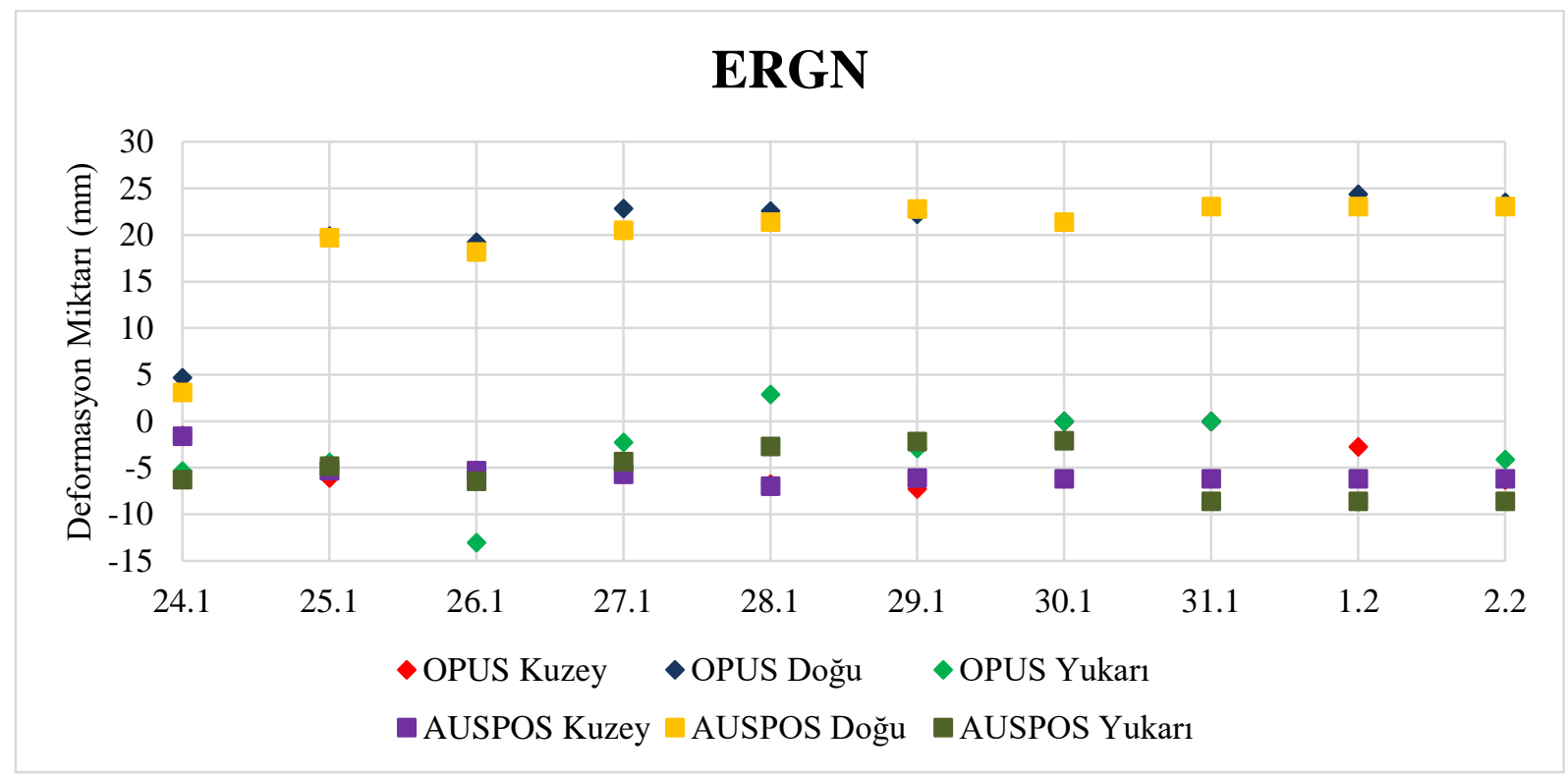

Şekil 19. ERGN TUSAGA-Aktif istasyonun deprem günü sonrası günler için deformasyon miktarlar1

OPUS ve AUSPOS web tabanlı servislerin MALY TUSAGA-Aktif istasyonu için belirlenen deformasyon miktarları Şekil 20' de gösterilmiştir. Her iki servisten elde edilen sonuçlar karşılaştırıldığında tüm yönlerde birbirleriyle uyumlu sonuçlar elde edilmiştir. AUSPOS servisi sonuçları kullanılarak yapilan deformasyon miktarları hemen hemen her gün için OPUS servisi sonuçları kullanılarak hesaplanan deformasyon miktarlarından az da olsa büyük çıkmıştır. Burada dikkat çekici olan durum ise 31 Ocak 2020 tarihinde her iki web tabanlı değerlendirme servisinin Doğu ve yukarı yönlü hareketin sırasıyla yaklaşık $-2 \mathrm{~cm}$ ve $1.3 \mathrm{~cm}$ olmasidir. Bu duruma Sivrice-Elazığ merkezli 31 Ocak 2020 tarihinde yerel saate göre 23:32' de meydana gelen 4.8 büyüklüğündeki deprem neden olmuş olabilir. Çünkü bu gündeki depremin kuvveti diğer günlere göre fazladir.

\section{MALY}

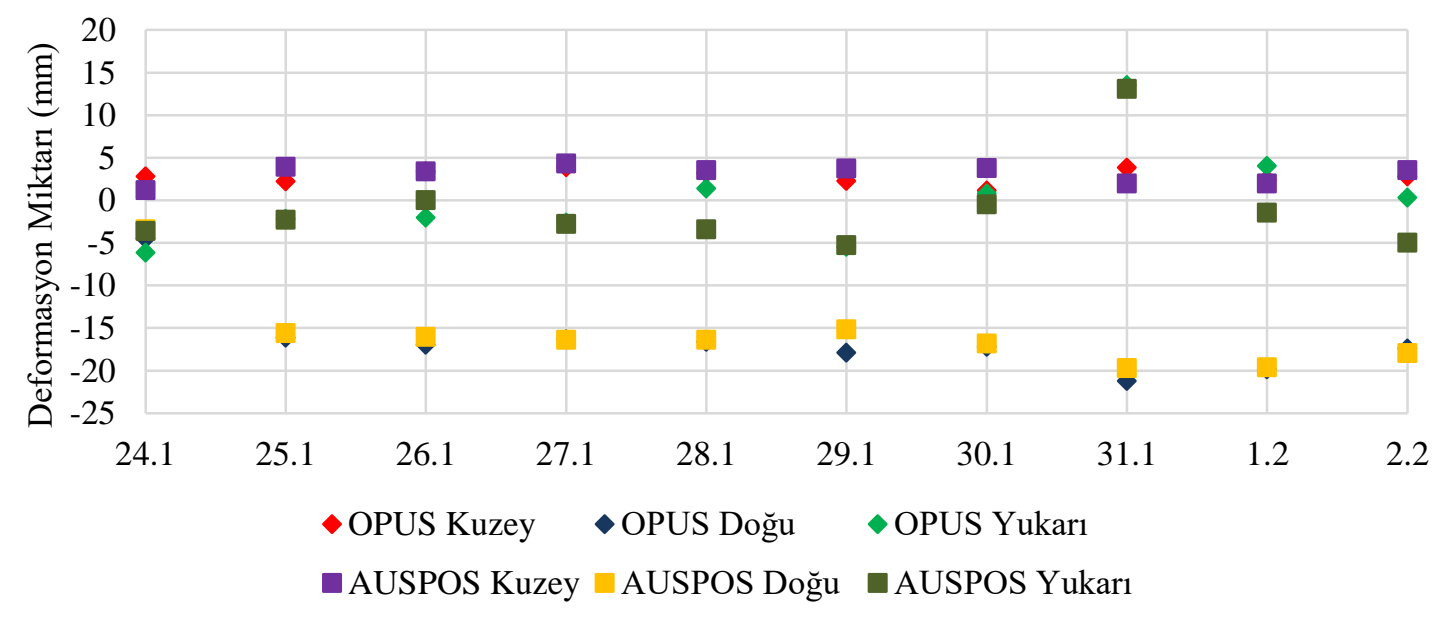

Şekil 20. TUSAGA-Aktif istasyonun deprem günü sonrası günler için deformasyon miktarları 
OPUS ve AUSPOS web tabanlı servislerin SIV1 TUSAGA-Aktif istasyonu için belirlenen deformasyon miktarları Şekil 21' de gösterilmiştir. Her iki servisten elde edilen sonuçlar karşılaştırıldığında tüm yönlerde birbirleriyle uyumlu sonuçlar elde edilmiştir. Çalışmada kullanılan diğer TUSAGA-Aktif

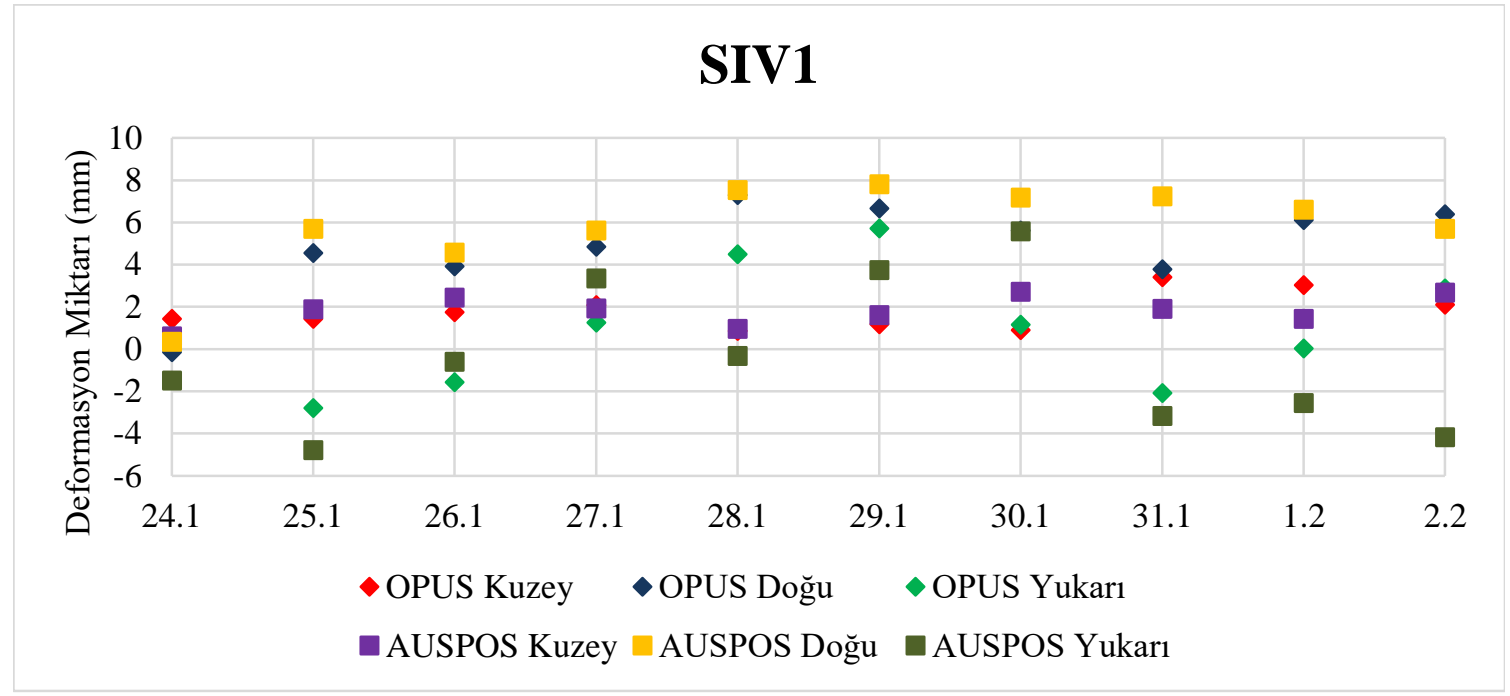

Şekil 21. TUSAGA-Aktif istasyonun deprem günü sonrası günler için deformasyon miktarları

\section{Sonuçlar}

24 Ocak 2020 tarihinde Doğu Anadolu Fayı üzerinde Sivrice-Elazı̆ merkezli saat 20:55, de aletsel büyüklüğü $\mathrm{MI}=6.6$ $(\mathrm{Mw}=6.5)$ olan şiddetli bir deprem meydana gelmiştir. Bu sebepten dolayı kullanıcılar tarafindan aktif olarak kullanılan TUSAGA-Aktif sistemini oluşturan istasyonların konumlarının kontrol edilmesi gerekmektedir. Çalışma kapsamında rölatif konumlama yapabilen Online Positioning User Service (OPUS) ve Online GPS Processing Service (AUSPOS) değerlendirme servisleri kullanılmıştır. $\mathrm{Bu}$ servisler sayesinde farklı istasyonlara göre konum belirlenebilmektedir. Web tabanlı sistemlere günlük GNSS verileri yüklenmiş ve sonuç raporları e-mail yoluyla elde edilmiştir.
Sonuçlara göre, ELAZ TUSAGA-Aktif istasyonunda yatay yönde yaklaşı $6 \mathrm{~cm}$ ' lik deformasyon; ERGN istasyonunda yatay yönde yaklaşık $2 \mathrm{~cm}$ ' lik deformasyon; MALY istasyonunda yatay yönde yaklaşık 1.7 cm' lik deformasyon; SIV1 istasyonunda yatay yönde yaklaşı $7 \mathrm{~mm}$ ' lik deformasyon meydana gelmiştir. Yukarı yönde ise ELAZ, ERGN, MALY ve SIV1 TUSAGA-Aktif istasyonlarında çoğunlukla anlamlı bir hareket gözlemlenmemiştir. Fakat ELAZ TUSAGA-Aktif istasyonunda her iki web tabanlı değerlendirme servislerine göre 28 Ocak 2020 tarihinde 1 cm' lik hareket gözlemlenmiştir. Yukarı yönde diğer bir farklı sonuç, ERGN istasyonunda OPUS değerlendirme servisinin AUSPOS değerlendirme servisine göre bazı günlerde anlamlı hareket sonucu vermesidir. 
Hareketi anlamlı çıkan günlerden 26 Ocak 2020 tarihinde $-1.3 \mathrm{~cm}$ ' lik yukarı yönde hareket bulunmasına rağmen bu durum OPUS servisinin hatası olarak düşünülmektedir. Bu durumun tersi durum ise MALY istasyonunda AUSPOS servisinin 31 Ocak 2020 tarihinde $1.3 \mathrm{~cm}$ ' lik yukarı yönlü hareketin anlamlı olmasıdır. $\mathrm{Bu}$ da diğer durum gibi AUSPOS servisinin değerlendirme hatası olarak kabul edilebilir. SIV1 istasyonu için yukarı yönlü hareketlerin hiç biri anlamlı çıkmamıştır.

Genel olarak belirlenen yatay yönlü hareketler deprem sonrası günlerde devamlılık arz etmektedir. Bu durum diğer koşullar göz ardı edilmiş bir biçimde istasyonların depremden etkilendiği anlamina gelebilir. Her iki web tabanlı değerlendirme servisinin sonuçları rölatif olarak belirlenmiş farklı noktaların koordinat sonuçları ile karılaştırılabilir. Bu sayede değerlendirme servislerinin deprem hareketlerini ne derecede belirleyebildiği açıkça görülebilecektir. $\mathrm{Bu}$ anlamda bir sonraki çalışmanın bu konu üzerinden yapılması düşünülmektedir.

\section{Teşekkür}

Yazarlar bu çalışmada kullanılan TUSAGA-Aktif ağına ilişkin GNSS verilerinin sağlanmasında Tapu ve Kadastro Genel Müdürlüğü ile Harita Genel Müdürlüğü' ne ve elde edilen değerlendirme sonuçları için OPUS ve AUSPOS web tabanlı GPS veri değerlendirme servislerine teşekkür ederler.

\section{Kaynaklar}

Aktuğ, B., Dikmen, U., Doğru, A., Özener, H. 2013. "Seismicity and strain accumulation around Karliova Triple
Junction (Turkey)", Journal of Geodynamics, 67, 21-29.

Aktuğ, B., Özener, H., Doğru, A., Sabuncu, A., Turgut, B., Halıcıoğlu, K., Yılmaz, O., Havazl1, E. 2016. "Slip Rates and Seismic Potential on the East Anatolian Fault System Using an Improved GPS Velocity Field", Journal of Geodynamics, 94-95, 112.

Altınoğlu, F.F. 2019. "Elazığ ili ve çevresinin çizgisel yapılarının gravite verisine sinır analizi teknikleri uygulanarak belirlenmesi", Pamukkale Üniversitesi Mühendislik Bilimleri Dergisi, 25(6), 785793.

Ansari K., Çorumluoğlu Ö, Sharma S.K. 2017. "Numerical Simulation of Crustal Strain in Turkey from Continuous GNSS Measurements in the Interval 2009-2017', Journal of Geodetic Science, 7(1), 113-129.

B.Ü. Kandilli Rasathanesi ve Deprem Araştırma Enstitüsü Bölgesel DepremTsunami İzleme ve Değerlendirme Merkezi (BDTIM). " " 24 Ocak Sivrice-Elazı ̆ Depremi Basın Bülteni”, http://www.koeri.boun.edu.tr/sismo/2/24ocak-sivrice-elazig-depremi-2/, son erişim tarihi:16.03.2020

B.Ü. Kandilli Rasathanesi ve Deprem Araştırma Enstitüsü Bölgesel DepremTsunami İzleme ve Değerlendirme Merkezi. 'Deprem bilgileri - Büyük depremler",

http://www.koeri.boun.edu.tr/sismo/2/depr em-bilgileri/buyuk-depremler/, son erişim tarihi:16.03.2020

Bayramoğlu, B. 2020. "Doğu Anadolu Fay Zonu'nun, Palu Segmentinin, Üçdeğirmenler-Karşıbahçeler (Palu-Elazı̆̆) 
Arasinda, Paleosismolojik ve Morfotektonik Özellikleri”, Yüksek Lisans Tezi, Sivas Cumhuriyet Üniversitesi Fen Bilimleri Enstitüsü, Sivas, 1-49.

Bülbül, S., İnal, C., Yıldırım, O., Başçiftçi, F. 2017. "Velocity Estimation of Turkish National Permanent GNSS Network-Active Points Located at Central Anatolia Region", Bilge International Journal of Science and Technology Research, 1, 18-25.

Gelişkan, Ş. 2019, "Hassas Nokta Konumlama İle Deformasyonların Belirlenmesi" Yüksek Lisans Tezi, Selçuk Üniversitesi Fen Bilimleri Enstitüsü, Konya, 1-43.

Hartinger, H., Brunner, F. K., 2000. "Development of a monitoring system of landslide motions using GPS", 9th FIG Symposium on Deformation Measurements, Olsztyn, 29-38.

Kayın, S. 2019 "Van Gölü Civarının (Doğu Anadolu) Tektonik Gelişiminin Ve Deformasyonunun Paleomanyetik Çalışmalar İle İncelenmesi”, Doktora Tezi, İstanbul Teknik Üniversitesi Fen Bilimleri Enstitüsü, İstanbul, 8-9.

Khalıfa, A. 2018 "Morphotectonic Analysıs Of The East Anatolian Fault Zone (E. Turkey) Using Remote Sensing Technıques", Doktora Tezi, Istanbul Teknik Üniversitesi Fen Bilimleri Enstitüsü, İstanbul, 1-25.

Khalifa, A., Çakır, Z., Lewis, A., OWEN, L.A., Kaya, Ş. 2018. "Morphotectonic Analysis Of The East Anatolian Fault", Turkish Journal of Earth Science, 27, 110126.
Köküm, M. 2019. “Landsat TM Görüntüleri Üzerinden Doğu Anadolu Fay Sistemi’nin Palu (Elazı̆̆)-Pütürge (Malatya) Arasındaki Bölümünün Çizgisellik Analizi”, Gümüşhane Üniversitesi Fen Bilimleri Enstitüsü Dergisi, 9(1), 119-127.

Köküm, M., Özçelik, F. 2020. “A Case Study On Reassessment Of Historical Earthquakes: 1789 Palu (Elazı̆̆) Earthquake, Eastern Anatolia, Turkey", Bulletin of the Mineral Research and Exploration, 161(161), 1-10.

Kutlu Ünal, S. 2019 “Deprem Kavramı Algısı Ve Depreme İlişkin Değerlendirmeler; 8 Mart 2010 OkçularKovancılar Depremi Örneği”, Yüksek Lisans Tezi, Çanakkale Onsekiz Mart Üniversitesi Fen Bilimleri Enstitüsü, Çanakkale, 1.

Menekşe, A. 2016 "Probabılistıc Seısmıc Hazard Assessment For East Anatolian Fault Zone Using Planar Source Models", Doktora Tezi, Orta Doğu Teknik Üniversitesi Fen Bilimleri Enstitüsü, Ankara, 1-12.

Şanlığlu, İ., Başkan, G., Zeybek, M. 2019. "Elazığ-Karakoçan Depreminin TusagaAktif İstasyonlarına Etkisi” Selçuk-Teknik Dergisi, 18(2), 46-67.

Tan, A., Eyidoğan, H. 2019. "The Kinematics of the East Anatolian Fault Zone, Eastern Turkey and Seismotectonic Implications", International Journal of Engineering \& Applied Sciences, 11(4), 494-506.

T.C. İçişleri Bakanlığı, Afet ve Acil Durum Yönetimi Başkanlığı (AFAD). "24 Ocak 2020 Sivrice (Elazı ̆) Mw 6.8 Depremine İlişkin Ön Değerlendirme Raporu”, 
https://deprem.afad.gov.tr/downloadDocu

ment?id=1825, son erişim tarihi:16.03.2020

Yıldırım, O., Yaprak, S., İnal C. 2014. "Determination of 2011 Van/Turkey earthquake $\quad(\mathrm{M}=7.2) \quad$ effects from measurements of CORS-TR network", Geomatics, Natural Hazards and Risk, 5 (2), 132-144.

Yigit, C.Ö. 2016. "Experimental assessment of post-processed Precise Point Positioning for Structural Health Monitoring. Geomatics", Natural Hazards and Risk, 7(1), 360-383.

Yönlü, Ö., Altunel, E., Karabacak, V. 2017. "Geological And Geomorphological Evidence For The Southwestern Extension Of The East Anatolian Fault Zone, Turkey", Earth and Planetary Science Letters, 469, 114. 